\title{
Emergence and Evolution of ATM Networks in the UK, $1967-2000$
}

\author{
Bernardo Bátiz-Lazo* \\ (Forthcoming Business History)
}

\begin{abstract}
Research in this article traces the origins of a process of competitive change in British retail financial markets by looking at the emergence of cash dispensers technology, how it transformed into Automated Teller Machines (ATM) and how proprietary ATM networks gave way to total interoperability of cash withdrawals through a single common switch. Cash dispensers were an industry specific innovation developed by British manufacturers (e.g. Chubb and De La Rue) who, in turn, were overtaken by U.S. (e.g. NCR) and German (e.g. Siemens-Wincor) manufacturers. However, as the ATM became a global technology some of the leading providers (i.e. Burroughs, IBM and NCR) kept manufacturing and even their main design facilities in Scotland. The evolution of this technology illustrates changing boundaries of the banking organisation, the challenges faced by financial intermediaries to adopt on line, real-time computing and highlights the role of network externalities in financial markets. From a business history perspective, the ATM, electronic funds transfer and other retail payment media have been largely neglected by British historians and management scholars. Yet the success of automated cash dispensers as a distribution channel in retail banking epitomises a shift in bank strategy, namely how applications of computer technology moved from being potential sources of competitive advantage to being a minimum requirement for effective competition in retail finance. This article thus promotes the idea that the history of technology must consider its users, their strategies and business models in as much as business histories of the late twentieth century will be incomplete without attention to developments in information and communications technologies.
\end{abstract}

Key words: banks, building societies, cash dispensers, ATM, technological innovation, diffusion, UK, networks, payment systems.

\footnotetext{
* Senior Lecturer in Business and Accounting History, School of Management, University of Leicester.
} 


\section{INTRODUCTION}

For most of the twentieth century, financial intermediaries working in retail markets and particularly those active in loans and deposit taking were the main channel for monetary control. This in the absence of secondary markets for government debt and as governments anticipated changes in the business cycle by introducing qualitative and quantitative criteria to allocate credit. Moreover, in Europe business organisations financed themselves primarily through bank credit rather than open market transactions. The decades that followed the Second World War saw cheques rather than bills and coins becoming the predominant medium of retail payment. A significant and sustained increased in the number (but not the value) of cheques to be cleared has been identified by a number of studies as one of the key motivations for banks on both sides of the Atlantic to automate. ${ }^{1}$ The automation of internal processes during the late 1950 s and the 1960s together with innovations in products and services (e.g. credit cards), eventually led to the creation of electronic fund transfer systems (EFTS) in the 1970s and 1980s as intermediaries brought retail branches 'on line' at the same time that computers and computer networks were increasingly used for inter-bank payments. ${ }^{2}$

A key element in the implementation and expansion of EFTS was the creation of networks of self-service cash withdrawal machines commonly known as cash dispensers and automated teller machines (ATM). In today's global economy the ATM is ubiquitous. They facilitate travel and have helped to redefine urban and global space. The ATM is an expensive, industry specific piece of capital equipment which also embodies the first step in multi-channel delivery strategies for the provision of retail banking services. The ATM has been heralded as a typical software application, 'on which a customer presses a sequence of buttons that causes the computer network to perform a complex set of operations correctly ... the customer is programming the bank's computer. ${ }^{3}$ But as the research that follows illustrates, a number of things had to happen before the ATM achieved 'software status'.

The importance of cash dispensing technology in US banking was perhaps first noticed by Richardson's pioneering contribution. ${ }^{4}$ But neither Richardson nor other systematic studies on the evolution of ATM networks within the business and 
technological history of US banking challenged conventional wisdom as to the creation and diffusion of different versions of cash dispensing technology.

Hopton, Kirkman and Howells \& Hine summarise developments in the British payment system. ${ }^{5}$ Coopey and Barrie touch on the emergence of ATM in the UK from an historical perspective. ${ }^{6}$ Coopey offers evidence as to the emergence of cash dispensers and its business and technological links with credit cards as the backbone of British EFTS. Some elements of this story are also found in Ackrill and Hannah's authoritative history of Barclays Bank. ${ }^{7}$ Meanwhile, Barrie positioned the ATM within the overall process of technological change of UK banks. However, none of these contributions provide a detailed account of the transformation of cash dispensers into ATM networks.

Alongside systematic studies from an historical perspective, there is an extensive body of cross-sectional analyses by scholars who have explored marketing dimensions of ATM, industrial policy dimensions and the ATM as a computer network. A recent survey by Vázquez-Alanís, identified two areas that group academic contributions in the broad areas of economics and management, namely performance effects and networks effects. ${ }^{8}$ Performance effects aims to tell how investments in ATM relate to greater operational efficiency and this, in turn, to changes in market share, interest and non-interest income. A central claim is that possibilities of informational asymmetries that can be exploited through early adoption of new information technologies, such as ATM networks, can result in first mover advantage.

Contributions dealing with network effects focus on changes in the number of locations from which users are able to access bank records using an ATM. It is claimed that there are location-specific costs and that fixed specific costs (i.e. sunk or irrecoverable costs) are not important to explain the growth of ATM networks. These contributions are further divided in two sub-categories. A first sub-category involves studies dealing with the size of the network. Of particular importance are network externalities, role of participants, role of 'switches', economies of scale or scope in the provision of services, and density (i.e. number of devices per capita or $\mathrm{km}^{2}$ ). A second sub-category deals with interchange fees, that is, sharing costs of proprietary networks. This involves competitive dynamics between financial intermediates, pricing of the fee 
itself and customers' willingness to pay for the fee. In the US, recommendations for public policy around concerns for interchange fees has received substantial attention by legal scholars and those versed in the economics of industrial networks. ${ }^{9}$

Beyond Vázquez-Alanís’ performance and network effects, there might be two other areas of research. Both of these are in need of empirical and analytical attention. First, the effects of computerisation of banking on the money supply and monetary control. This is an area that considers the interaction of banks' corporate strategy and bank regulators in the creation of network standards. An area exploring how the development of EFTS was influenced by decisions of banks' senior managers, changes in customer behaviour and preferences as well as policy goals of monetary authorities. Second, the role of ATM within interpretative studies of organisational change and information technology. ${ }^{10}$ However, both of these alternative research agendas are beyond the scope of my article.

In summary, the use of standards and the creation of networks has been documented. These studies have placed too much emphasis on technology and marketbased solutions while overlooking the corporate strategy motivating investments in expensive and highly industry specific devices such as cash dispensers. Archivallyinformed analysis of similar, but previously undocumented, developments on the part of UK banks and building societies, the emergence of EFTS and the creation and growth of ATM networks in Britain is the focus of the current research. A history of ATM networks in Britain offers an opportunity to explore both technological and strategic aspects of retail banking - an area comparatively neglected in the discussion of post-1945 British economic performance. Moreover, offers an opportunity to demonstrate how the history of technology must consider its users in as much as business histories of the late twentieth century will be incomplete without attention to developments in information and communications technologies.

\section{TECHNOLOGICAL KNOW HOW AND BANK STRATEGY}

As suggested by Revell and McAndrews, the ATM is a technology used for banking services, which embodies a machine incorporating a video display unit (VDU), keyboard, printer (to provide a record of the transaction or a summary statement) and other software 
and hardware that enables individuals using debit cards, credit cards or certain tokens to make cash withdrawals and/or deposits, balance enquiries, balance transfers (between accounts of the same customer, the customer and the bank or the customer and a third party) as well as other services, for which users may be charged a transaction fee. ${ }^{11}$ The ATM is thus seen as much more than a simple cash withdrawal device and as part of a self-service offering.

There are other interesting features of ATMs. For instance, a machine must be fitted with a miniature strong room to enable it to store and supply cash. A stainless steel fascia mediates between user and hardware to protect electronic equipment from adverse weather, vandalism and theft. A full-service ATM would offer all these features already mentioned and therefore, provide practically all the straight forward services a customer needs from a retail bank. One important exception being that regular payments and credits have to be arranged separately. A second important distinction appears when deposit facilities are provided because these are rarely more than the conventional night safe, leaving the bank to verify the amount deposited when the machine is cleared. Automatic currency exchange devices at airport halls suggested it was technologically possible for machines to identify and count notes and coins for some time. However, it was until circa 2005 when cash and coins were counted and credited to customers' accounts alongside cash distribution through self-service machines in the High-Street. ${ }^{12}$

Coopey has questioned whether the ATM embodies a single technology. ${ }^{13} \mathrm{He}$ considers that the "ATM is best viewed as the consolidation of a series of technologies and systems, developing independently, and some in turn picking up impetus from the development of the ATM itself. ${ }^{14}$ The potential coexistence of different technological solutions highlights the fact that senior managers of financial intermediaries can (and do) choose amongst alternative technological configurations. Choice empowers individual organizations to influence the evolution of these configurations rather than having to accept technological solutions determined by manufacturers. With these ideas in mind, British banking offers a particularly good example of user-driven change given that a highly concentrated market and densely populated retail branch network resulted in individual orders being large for North American standards. Indeed, throughout the 
twentieth century the likes of IBM, Burroughs and NCR worked hard to keep the custom of British banks, savings banks and building societies.

Revell called a cash machine an ATM as long as it provided at least one additional service to that of cash dispensing. ${ }^{15}$ As will be evident below, this distinction fails to ascertain that the first cash dispensers were stand alone devices which required human intervention to credit and debit a customer accounts. These early machines were no different to other contemporary technology in US and European retail finance such as mobile branches, postal deposits, drive-through and drive-in banking. All of these were in place during the late 1950s and 1960s as alternatives to 'brick and mortar' distribution of cash withdrawal and deposit. ${ }^{16}$ Instead, the success of cash dispensers enabled the deployment of ATM fleets from the mid-1970s onwards as characterised by electronic data processing technology, databases of customer information, software to manage electronic repositories and other hardware and software which enabled the device to credit or debit the customer account without human intervention. In other words, it is synchronous electronic data processing (EDP) at the point of contact with the customer the feature which distinguishes the cash dispenser from the ATM. This process of transformation required an intermediate state where the same device operated according to the context and choice of individual financial intermediaries, namely stand alone, synchronous or asynchronous communication to a central computer. The devices also transformed from being set up and wired to a single form of operation to a more general platform which allowed the storage of pre-programmed instructions (for their operation to suit purchasing specifications and the emulation of alternative vendors). It is only when the device achieves on line, real time communication at the point of contact with the customer which one can then say the ATM acts as a remote device that enables individual customers to interact directly, with ease, securely, reliably and unobtrusively with the financial intermediary's central computer (and thus become a 'true' software application as proposed by Ceruzzi). ${ }^{17}$

Initially, cash dispensing technology was perceived as a potential source of competitive advantage for individual banks. During the late 1970s and early 1980s proprietary ATM networks developed in the UK while the machines themselves transformed from simple cash dispensers to multi-tasking devices. After having reached a 
peak of almost 200 individual networks in 1986, amalgamation between banks and also amongst the networks themselves resulted in five ATM networks controlling some 78 per cent of transactions in the US by $2001 .^{18}$ Meanwhile in 1998 , there was only one single ATM network in the UK as participants developed full interoperability for cash withdrawal around a single common platform (e.g. LINK). Throughout this process of growth and consolidation, proprietary ATM fleets turned into a threshold capability for retail financial services, included the provision of these services by non-banking participants (e.g. food retailers and Independent ATM Deployers) and even the delivery of non-financial services such as topping-up mobile phone account balances.

The emergence of the first cash dispensers as the earliest form of ATM should be seen in the context of a long-term process of technical change and not only motivated as a short-term response to reduce cost structures. This view is supported when considering that mechanisation and automation permeate the evolution of British retail financial intermediaries throughout the twentieth century. ${ }^{19}$ For clearing banks and building societies, the 1960s saw the introduction of computer technology on the back of growing pressures in the labour market to source (cheaper) female clerical work, private and public initiatives to introduce electronic payment of wages, antagonistic government officials, growing inflation and greater variability of interest rates. Banks begin to grapple with ways to ease physical overcrowding within retail branches and an increasingly unionised work force, which was demanding the end of Saturday morning opening of retail branches. Indeed, how to articulate Saturday closing was a top concern for the Committee of London Clearing Banks in the early and mid-1960s. ${ }^{20}$ But it came about in 1969 and only after the introduction of cash dispensers. Meanwhile many building societies became active in developing retail branch networks while their mortgage loan portfolio expanded rapidly. ${ }^{21}$ The trustee savings banks (TSB) also used computer technology to tackle the decimalization of sterling, reduce back office work at branches while they amalgamated into a single provider in 1985.

But for a handful of instances such as the development of on line, real time retail branch network by the TSB or Barclay's fiasco with the Burroughs B8500, retail financial intermediaries usually resisted the uncharted novelties of the latest technology. Most banks and building societies selected career staff (typically from accounting or 
operational methods departments) to be trained in and head their computerisation efforts. As a result, the speed of computerisation was often 'conservative' but despite a few obviously inappropriate decisions made with regard to the adoption of technology, it appears that building societies, savings banks and clearing banks in particular, got things about right. ${ }^{22}$

In summary, research in this article proceeds while considering that executives of financial organisations had a degree of choice in adopting ATM technology to solve specific problems. These choices were influenced (but not determined) by a long-term process of technological change where learning around the adoption of mainframe computer technology was the most recent episode. However, other contextual forces should not be underestimated and these include the government's view of an increasingly inefficient banking sector, the government's 'buy British' computer policy, reluctance of staff and unions to continue with Saturday opening hours, staff shortages, internal and external pressures to reduce staff costs, limited space within retail branches when increased business had to be processed, great variance of interest rates, the introduction of decimal currency in 1971 and ascension to the European Economic Community in 1973.

\section{PROPRIETARY NETWORKS}

It is claimed that the development of cash machines in the US was influenced by learning around punched card tabulators and early computer technology. ${ }^{23}$ Geographical restrictions to retail branch banking also played an important role. ${ }^{24}$ Popular accounts link the first attempt at a mechanical cash dispensing technology to the Bankograph developed by Luther George Simjian, allegedly in $1939 .{ }^{25}$ I have documented elsewhere my challenge to the 'conventional wisdom' as to who 'invented' the cash dispenser as well as reassessed the contribution by Simjian. ${ }^{26}$ Suffice to say that Simjian's patent US3079603 was first filled in June 30, 1960 and the roll out of the Bankograph was delayed a couple of years. This was partially due to his Reflectone Electronics Inc. being acquired by Universal Match Corporation. ${ }^{27}$ The Bankograph was an automated envelope deposit machine and it did not have cash dispensing features. ${ }^{28}$ The Bankograph, however, embodied the preoccupation by US banks in finding alternative means to capture core deposits; while the concern of British banks was cash distribution. There 
also was a Japanese cash dispenser machine in operation in January $1967 .{ }^{29}$ Activated with a credit card rather than accessing current account balances, this technology had no immediate consequence in the international market.

The genesis of cash dispensing in the UK dates to three teams working independently of each other (namely Barclays Bank and De La Rue Instruments; Smiths Industries, Chubb \& Son's Lock and Safe Company Group (Chubb) and Westminster Bank; Midland Bank and Speytec). ${ }^{30}$ It is common knowledge that the first to market was one of the six machines in a pilot project installed by Barclays Bank in its Enfield retail branch in June 1967. This development was closely followed internationally as similar machines were in operation in 1969, namely at the Philadelphia National Bank in the US and the Umeda branch of the Sumitomo Bank in Japan.

Internally denominated De La Rue Automatic Cash System (DACS) but advertised as 'Barclaycash', the machines were called 'robot cashiers' by internal and popular press. ${ }^{31}$ Barclay's customers were issued vouchers, which carried information in punched card form (Figure 1). Customers applied in advance for the vouchers from Barclays (purchased from the retail branches during opening hours). These were valid for six months from the date of issue and prior to activating the machine, a manual signature was a first form of individual customers' identification and authorisation. By introducing the voucher in one drawer, an electronic signature (a second form of identification) activated a second drawer which, in turn, dispensed the fixed sum of ten pounds (in packs of one pound notes). The electronic signature was in the form of a six-digit identity number. Inside the machine a section of the voucher was guillotined to bring it to the standard size of a cheque. When the voucher was retrieved by bank staff, the transaction was processed like a cheque during normal banking hours.

\section{[Insert Figure 1 around here]}

Barlcaycash was admittedly seen as an 'experiment' but it was hoped that, in due course, the 'mini-bank' would achieve '...its dual role, as a 24-hour customer service and as a relief to ease banking-hour pressure on the branch's cashiers. ${ }^{32}$ Cash machines were never intended as a stand-alone device but part of a network (in this case, complementing 
the web of retail bank branches). Indeed, from the outset there were expectations that, if successful, similar machines would '...follow in airports and main-line railway stations..., 33

Other clearing banks followed Barclays lead, the Westminster Bank installing their first machine in July 1967 at its retail branch next to Victoria railway station. ${ }^{34}$ During the following four months nine other machines were also operational (two more in London and seven in mayor provincial cities such as Bristol, Nottingham, Oxford and Sheffield). The Westminster cash machines were all manufactured by Chubb. Customers were given plastic credit card sized cards with holes punched in them. ${ }^{35}$ The card was inserted into the machine and the customer keyed a four digit personal code (Figure 2). The Chubb MD2 dispensers delivered ten one pound notes in a pack - but 'if desired, it could easily be arranged to dispense varying amounts of say $£ 5, £ 10, £ 15$, $£ 20$, etc. ${ }^{36}$ At the bank's request during the design stage, the customer's card was retained by the MD2 and returned to customers through the post for future use.

\section{[Insert Figure 2 around here]}

Other banks were quick to adopt the cash dispenser idea but given the exclusivity agreement signed between De La Rue and Barclays, they became users of the Chubb MD2. For instance, also in 1967, Martins Bank installed its first machine in Liverpool. ${ }^{37}$ The National Provincial Group did likewise in January 1968, on the outside of the District Bank's Piccadilly branch in Manchester. ${ }^{38}$ The Royal Bank of Scotland (RBS) was the first to introduce a 24 hours service north of the border. ${ }^{39}$ By the end of 1968 , RBS's 'Automated Cash Dispensers' were providing similar services in 25 branches throughout Scotland and in London.

The Chubb MD2 became the machine of choice for British banks in the late 1960s and early 1970s. Barclays, on the other hand, stuck to De La Rue. ${ }^{40}$ Eighteen months after the initial test at Enfield, in November 1968, Barclays ordered 75 automatic cash dispensers from De La Rue at an approximate cost of half a million pounds. ${ }^{41}$ The design of these machines benefited from learning during the trial period of the prototypes. For instance, within a few days of operations, Barclays' first cash dispenser had been 
vandalized. ${ }^{42}$ The new design was to have a single drawer rather than the prototype's two. By February 1973, there were 250 De La Rue Barclaycash machines in operation throughout Britain. ${ }^{43}$

As was the case for the De La Rue's DACS machines, in the absence of a video display unit (VDU) the Chubb dispenser communicated with the customer using fixed light signals (primarily to indicate the card or voucher had been accepted). ${ }^{44}$ From the outset banks adopting the Chubb MD2 and DACS chose to fix the cash dispenser to the exterior wall of the branch rather than in the banking hall. This was possible through a stainless steel exterior and interior cladding of thickened armour designed against attack making the MD2 operational 24 hours per day. ${ }^{45}$ Here it is important to note the number of engineering challenges the different teams faced as, for instance, never before had any other machine positioned electronic circuits so close to enduring changing weather, impinging the need to develop metal alloys that would not easily succumb to the inclemency of seasonal changes and different climates within the British isles.

A fact often over looked in the popular accounts of the emergence of cash dispensers and ATMs, is that the introduction of credit cards and cash dispensers marked the first time that technology was really modifying services for retail customers since computerisation began in the late 1950s. Changes were beyond the superficiality (from a customer perspective) of pre-printed stationary, mechanical annotations or magnetic characters in cheques. The introduction of these machines for the first time allowed customers to engage with their financial institution regardless of location instead of a single retail branch. This was not lost on senior managers, who were keen to advertise it:

CASH DISPENSER SERVICE - ... The service is free to Westminster Bank customers who, irrespective of the branch at which they may bank, may draw from the Victoria Dispenser. It is available 24 hours a day, 365 days a year.... Already over 6,000 customers have applied for cards. ${ }^{46}$

Together with the development of direct-selling capabilities around credit cards, the introduction of cash machines were marking the start of a trend where more work was processed centrally and less at retail branches - with the subsequent loss of their autonomy as a 'self-sufficient production unit' ${ }^{47}$ : 
One of the most attractive features of [Royal Bank of Scotland's 24 hour Cash Dispensing Service] is that you do not have to be an Account Holder at a Cash Dispenser Branch. You simply apply to your own Branch and you will be supplied with a [centrally generated] special cash card and your own personal code number. ${ }^{48}$

As was the case in the US due to legislation on retail branches and in spite of 'national' retail bank branch networks, banking in the UK was highly localised. Customers of financial intermediaries were expected to develop long-term relations with a single retail branch. The introduction of cash dispensers and credit cards was thus a response to an increasingly mobile population ${ }^{49}$ as much as a response to a drive for cost control (given the opportunities to lower encashment demands on human cashiers during banking hours and to make better use of retail bank branch space).

But as suggested in the quotes above, individual banks aimed to develop their own networks of cash dispensers, in the expectation that larger proprietary networks would be an advantage over intermediaries with small networks or even without any cash dispenser. Selection of the location for the first machines was given careful consideration. Explaining the reasons why Enfield and not a large city such as London, Glasgow or Edinburgh was selected as the first site, Barclays argued that the town had a '... model cross-section community, fairly self-contained; it is not too far from London, the branch has a good pavement façade, sufficiently high windows and enough space inside for the safe, and town-planning permission was readily given. ${ }^{50}$ Five more Barclaycash machines were installed by the end of that Summer in towns with similar characteristics, namely Hove, Ipswich, Luton, Peterborough and Southend.

The cost of adoption was substantial. This in terms of the machine itself. But also in terms on servicing as the first prototypes were prone to frequent faults and displacement of space within the retail branch as many were quite bulky. Nevertheless, banks in the Europe and North America were taken to the idea of cash dispensers while manufacturers alongside instrument maker De La Rue and security systems Chubb then emerged from a range of sectors - each with their own competitive dynamics. Notably most came from the US such as Diebold, Money Machine, Digital Security Systems and 
Docutel (the spin-off of baggage handling equipment manufacturer Recognition Equipment Inc. and wrongly hailed as the inventor of the ATM) ${ }^{51}$ as well as mainframe computer manufacturing companies such as NCR, IBM and Burroughs. ${ }^{52}$ There was also Omron-Tatesi and Fujitsu in Japan, Siemens and Nixdorf in Germany, and Italy's Olivetti. Many other smaller outlets emerged, particularly in Europe as each individual manufacturer coerced their own governments and their own banks to be protective:

throughout Europe you had so many rules and regulations in the 1970s that the emerging industry was slow to grow and slow to create something that was useful and marketable. Until the early 1980s none of them was easy to use or particularly reliable, apart from Chubb all of them were large, none of them was on line, interlinked, easy to change, alter or adapt and they had all these faults that they carried with them. They were so difficult to use that when the customers got out there and tried to use them, didn't quite know what they were doing, they were unreliable and most of the customers tried them once and didn't seem to help, so the usage rates were extremely low... then there was Burroughs [in the UK] and there was Docutel in the United States and then there were the Japanese..., but IBM was the only one who really had a system, had the potential at that time take over the market. [Because they] were truly international and because they had the mainframe control and all of the control of the software into the systems. ${ }^{53}$

\section{FROM CASH DISPENSER TO ATM}

As mentioned, early cash machines retained the access card or voucher after the transaction. Customers' accounts were debited when the voucher or card was retrieved from the machine after use and the branch (where the cash dispenser was located) informed the customer's branch. Chubb cards were posted back to the customer together with the statement of account or returned the following time the customer's passbook was updated. ${ }^{54}$ Barclaycash vouchers were non-returnable. The card and voucher were issued only if the customer had sufficient funds (or the manager of the retail branch wanted to give some credit). Mechanisation of cash withdrawal meant that individual banks could, if they so wished, continue with their system of accounting control of customers at retail branches. There was no need for centralised records as the cash dispenser was in effect a 
stand-alone machine. As had been the case with accounting machines, cash dispensers offered greater efficiency rather than an alternative way of operation. ${ }^{55}$

As the 1970s progresses, slowly but steadily cash dispensers stopped being standalone machines and developed on line, real-time capabilities. ${ }^{56}$ This as electronic data interchange networks, solid state memory, programming languages, integrated circuits, etc. became readily available. Financial intermediaries deployed mini-computers as well as synchronous and asynchronous electronic fund transfer (EFT) terminals to support further moves to EDP centralisation.

The transformation from the cash dispenser to the ATM in the UK started when Lloyds Bank deployed its first 'on line' dispensers in December 1972. Lloyds had 24 cash dispensers in operation and was said to have been cautious with the 'first generation' of machines. ${ }^{57}$ C. B. Howland, General Manager (Organisation), opined in 1970:

for many months we have been undertaking studies in depth into the possible uses and developments of cash dispensers.

It was, in fact, because we looked at them so closely that we came to the conclusion early on that the machines were very much first generation types, not nearly reliable enough and quite insufficient field trialled, thus explaining why we have not installed too many too quickly.

We are ready for 'on line' versions but the machines are not here yet. 'On line' in this context means that before we pay out to a customer reference is made by the machine to the computer to ensure that funds are in the account. Thus, all customers who want the facility could have it without being concerned for their funds. ${ }^{58}$

Lloyds' aim of linking dispensers to its computerised accounting system implied changing processes and procedures in place for almost 50 years. ${ }^{59}$ Introducing a device linked to the central computer, able to check the customer's balance before each withdrawal, dispensing variable amount according to the customer's requirements and being available to all customers would involve the creation of both a database and database management system (DBMS). That is, migrating customers' records into 
electronic form but also the creation of software (and underlying hardware) that would mediate and give access to the tables and records for which a given user had been authorised. This was a significant step as thirty years later integrated database and DBMS would be the essence of internet banking as well as virtually every administrative process in business, science or government. ${ }^{60}$ Lloyds thus had its computer system ready on time for decimalization while the likes of Barclays did not following the Burroughs B8500 fiasco. ${ }^{61}$

Dispensing cash 'on line' for Lloyds developed as part of the preparations for the changeover to decimal currency: after five years of development efforts to computerise its back office systems, Lloyds was the first clearing bank to move its customer accounting systems away from retail bank branches to a central computer in November $1970 .^{62}$ At the time, Lloyds had 154 branches and 801 sub-branches, some five million accounts (including nearly three million current accounts) and at least three computer centres (reflecting its core business areas, namely one in London, one in Birmingham and a dedicated centre for cheque clearing in the City - which processed between 650,000 and one million cheques daily). Lloyds claimed to have invested $£ 25$ million in computers ( $£ 15$ million already invested and $£ 10$ million on order) as well as doing it 'less expensive' than others.

Equipped with a database of customer records as well as processes and procedures to deal with them centrally, it was possible to consider 'on line' cash withdrawal. After all, commercial applications based on synchronous EDP had been in place for a number of years (such as airline reservation systems). The computerisation of the customer accounting system resulted in Lloyds developing a 'successful partnership with IBM' ${ }^{63}$ It was based on this 'partnership' that the 'on line' dispenser was designed and built. ${ }^{64}$ In June 1971 an order for 500 machines, costing nearly $£ 3.5$ million in total was placed with IBM for delivery of cash dispensing equipment which offered customers the choice of variable amounts of cash up to a maximum of $£ 50$ at any one time (up to $£ 20$ in one pound notes and up to $£ 50$ in five pound notes). ${ }^{65}$

The first so-called 'Cashpoint' made its public debut on December 1972, with the rest introduced progressively to retail branches through 1973 and $1974 .{ }^{66}$ The machine 
was initially only available in the UK and was innovative as it was the first widely deployed machine to be operated by a plastic card with a magnetic stripe on the back (containing the customer's account number and the branch sorting code) ${ }^{67}$ There was still no VDU as instructions to the customer were relayed through a separate panel made out of plastic stripes with lights at the back. There were perhaps more moving parts than in the Chubb MD2, as the keyboard would only be exposed after the card was validated, notes were first dispensed into a concealed cash tray (which was then lowered over the keyboard for the customer to collect the cash) and the card itself was return to the customer to end the transaction. ${ }^{68}$

The 'Cashpoint' was thought to work within banking halls, 'through the wall', and 'in locations away from banking offices'. ${ }^{69}$ By December 1976, 630 'Cashpoint' machines were operational in 430 branches and this included Lloyds' first 'through the wall' machine. The long period to roll out the 'Cashpoint' was partially explained by the high cost, low reliability and availability of telephone lines for EDP. These hampered possibilities for a generalised synchronous updating of customer records solution of the scale UK banks required. Instead and driven by developments outside the UK, vendors offered different modes of operation. Some models stored transaction information electronically in themselves (first in magnetic tape cassettes and later in floppy disks). This was transmitted for general clearing at the end of the day through an EFT terminal (such as the Burroughs RT500). Others informed a mini-computer within the branch, which kept balances and corresponded with the central computer. The advent of storage within the machine also opened possibilities for customising the device through software applications as well as storing different types of records (such as a table of cancelled or overdrawn accounts). A combination of 'stand alone', batch and synchronous processing machines thus characterised the 1970s.

Barclays' immediate response to Lloyds' 'Cashpoint' was to review its own strategy. In February 1973, an urgent feasibility study by the Management Services Department for the Automation Committee considered that the $250 \mathrm{De}$ La Rue dispensers were unreliable, the paper voucher system inconvenient, functionality limited and the role of managers of retail branches in promoting their use unsatisfactory, as vouchers had been issued to only 116,000 individual customers. ${ }^{70}$ The report recommended adopting 
machines with card activated, on line, variable amount dispensers. Owing to the lack of an on line verification capability, balances of both current and Barclaycard (i.e. credit card) accounts could only be ascertained through data encoded on the magnetic stripe. It was estimated that developments to suit Barclays' needs would require some 12 to 18 months with IBM or Burroughs (longer if choosing Chubb or De La Rue) and each machine would cost at least $£ 8,000$ (including installation).

Barclays decided to proceed and make necessary changes for the new generation of cash dispensers. This required a third computer centre, centralization of accounting information, development of a dedicated electronic data interchange network, computer terminals in retail branches and microfiche equipment. Initially $£ 83.4$ million were budgeted (including $£ 2$ million for on line automated tellers alone) for expenditure between 1974 and 1979. But this was soon to be insufficient. Adjustments and variations made as early as March 1974, raised the forecast to $£ 93.2$ million. $^{71}$

In May 1975, a more sophisticated auto-teller services, called 'Barclaybank' was advertised. $^{72}$ The announcement followed a decision made by Barclays's Automation Committee to order 100 NCR 770 Self-service Financial Terminals in June $1974 .^{73}$ The first retail branches to offer the new machines were High Street and Cornmarket Street, Oxford. $^{74}$ Shortly after, in September 1975 NatWest introduced its first NCR 770 (advertised as 'Servicetills'). ${ }^{75}$ The first two machines installed in January 1975 were for staff use only. Two more were operational in banking halls in April and May and therefore limited to banking hours. But the machine that which came into operation in the Croydon branch in September was external and therefore provided service to the public all year round. ${ }^{76}$ By the end of 1977, NatWest had 100 NCR 770 machines in operation alongside 406 Chubb MD2 and MD4 dispensers while 75,000 cards had been issued to customers. $^{77}$

Designed in the US with very similar in functionality to the IBM-Lloyds 'Cashpoint', the 770 operated using a dedicated plastic card with magnetic stripe. They were released in 1974 to allow 24 hours cash withdrawal, envelope deposits as well as requests for cheque books, statements and account balances. ${ }^{78}$ The 770 had a concealed cash tray (that was later exposed) and guided the customer through a moving drum of 
film (with back light). Encoded within the card there was a magnetic stripe which stored a personal credit limit and personal identification number that allowed individual customers to withdraw cash in varying amounts. ${ }^{79}$ The 770 could be located in the banking hall or 'through the wall'. One limitation to the service was that NatWest balance enquiries were only available during hours of the 'teleprocessing day' (08.00 to 18.00 hrs). ${ }^{80}$ Another related to taking deposits. As had been the case in previous models, the 770 was capable of accepting and storing envelopes with cash and cheques for deposits (which would have to be validated by bank staff). To support the EFT through retail branch network, in November 1976 NatWest ordered 2,000 B80 small mini-computers from Burroughs at an estimated cost of $\$ 18$ million dollars. ${ }^{81}$ Barclays followed suit ordering 500 B80's in 1977 and 500 B90's in $1980 .{ }^{82}$

Also in 1975, Burroughs launched a competitor to the NCR 770, the TC750 with a price tag ranging from $\$ 10,500$ to $\$ 12,000$ (equivalent leases valued at $\$ 303$ to $\$ 344$ per month, per device) ${ }^{83}$ Advertised as 'an intelligent, programmable terminal', it sought to reduce maintenance costs by being fully compatible with its predecessor (TC700 model) as well as other EFT terminals (such as the popular TC500). This offered financial intermediaries a hardware upgrade without modification to the host's computer programmes while also enabling the same engineer to service a range of machines during the same call. Other features included updating passbooks (while aiming at mutual financial institutions) and saving in communication costs by using the same line as other terminals. The TC750 had two magnetic tape cassette stations as an extension of memory. One hosted instructions to customize operation. The other stored transaction information when off line as well as tables of customer card numbers that had been cancelled or had to be retained. These cassettes allowed the machine 'to operate independently of the data communications network or the central computer.' A couple of years later, programming capabilities allowed the TC750 to emulate IBM terminals.

The TSB adopted Burroughs cash dispensers. Meanwhile, the bulk of NatWest's and Barclay's NCR 770 machines were to be manufactured in Dundee, Scotland. ${ }^{84}$ The move to Scotland resulted from NCR's strategy to relocate production outside of Dayton, Ohio during the 1970s. ${ }^{85}$ The plant in Dundee originally was established in 1946 and initially the production of ATMs aimed at servicing only the "emergent European and 
British markets'. ${ }^{86}$ During the move a new model was rolled out in 1978, the NCR 1780. This kept many of the features of the 770 except that it was the first NCR ATM to be fitted with a VDU. ${ }^{87}$

For employees at Dundee, the relocation of the ATM production was an opportunity to apply expertise in mechanical engineering to an electronic product. ${ }^{88}$ Unfortunately the first 1780 s were hampered by a non-dedicated mix of components, some of them manufactured elsewhere. Performance of the 1780 was unreliable, orders were cancelled and one point Barclays even refused to take delivery (with subsequent damaged to NCR's reputation). To remedy the situation and after a couple of years of courting him, a Scott named Jim Anderson was appointed head of the Dundee plant in 1979 with a mandate to bring about a radical change in production quality, focus on the manufacturing of a handful of ('world beating') products and lift employee morale.

Improved performance saw the functionality of the NCR's ATMs expanding rapidly. For instance, changes implemented by Adamson included introducing a customer friendly VDU as well as delivering cash horizontally (i.e. long side) rather than vertically (i.e. short side) thus reducing jams by increasing contact and control of individual notes. In 1981, the 1780 allowed transfer of funds, payment of bills and the option of dispensing one or two currency denominations while featuring a keyboard with tactile and audible feedback, integrated 9x7 dot matrix printer (30 characters per line), transparent door (to protect from vandalism and weather), modular design (to enable choice between off-line cash dispensing or full service but more important, to compartmentalise faults so if one component failed the machine continued to be operational) as well as data encryption for added security of both customers and the financial institution. ${ }^{89}$ These developments came not from the foresight of engineers at manufacturers but from Adamson actively courting banks as well as ultimate consumers for feedback on their interaction with cash machines.

In 1984 NCR launched the 5070, considered the first full function machine while offering transfers, payments, printing of detailed statements and envelope deposits. ${ }^{90}$ This model resulted from Adamson's team out-manoeuvring Dayton-based engineers and effectively relocating the design of cash machines within NCR to Dundee. The features 
and operability of the 5070 was so advanced for its time that other manufacturers were only at their planning stage and thinking of offering similar features three or four years down the line. This 'wee outfit' was thus very much on its way to dominate the cash dispensing market.

As the technology evolved, so did the number of providers with the subsequent wave of disposals and amalgamations. Indigenous manufacturers who had failed to achieve economies of scale were the first to exit. This included Chubb whose involvement in the early days through the manufacture of cash dispenser had increased when it bought all the manufacturing, assets, patents and stock in cash dispensing of Smiths Industries for $£ 218$ thousand in August 1973. ${ }^{91}$ In 1976, Chubb acquired Gross Cash Registers Ltd. ${ }^{92}$ Together they formed the origins of a company called Chubb Cash. $^{93}$ As the 1970 s drew to a close, observers were alert that replacement demand for cash registers, office machines and cash dispensers initially spurred by decimalisation, was likely to benefit the likes of Chubb. ${ }^{94}$ Results, however, were disappointing. Chubb had introduced a second generation machines (an 'on line' whole-in-the-wall called MD4 and a lobby machine called MD6000 both circa 1975) but the integrated circuits revolution simply escaped the company. By 1980, Chubb Cash Ltd., the company that manufactured and supplied electronic and electromechanical cash registers, automated tellers and point-of-sale-systems, had considerably deteriorated its trading performance and reported operating losses of $£ 4.7$ million (including research and development costs to manufacture a new cash dispenser). Shortly after, in 1982, Chubb exited the cash dispenser market for good. ${ }^{95}$

By 1990 the likes of Burroughs, De La Rue and Docutel had abandoned the manufacturing of cash dispensers as well. But the year 1990 was memorable for two reasons. First, it was the year IBM withdrew from ATM manufacture. ${ }^{96}$ A move which was influenced by IBM's lack of success in that market in as much as the restructuring of its business portfolio away from manufacturing into software development and consultancy. Secondly, NCR became the undisputed leader as marked by the manufacturing of its $10,000^{\text {th }}$ ATM. A machine sold to Barclays Bank who, using the 'Barclaybank' banner, installed it as a working exhibit in the Science Museum 
(Kensington, London). ${ }^{97}$ In 2007 , however, a change of policy within NCR resulted in ATM manufacturing relocating to Eastern Europe.

\section{SHARED NETWORKS}

In 1981, a decade after Lloyds installed its first 'on line machine', NatWest had 500 NCR dispensers in operation (a combination of 770 and 1780), a figure that rose to 600 in June 1982. The sharp increase in machines at NatWest was not unique. Towards the end of the 1970s other banks had also decided to increase their rate of adoption: 'The Barclays cash dispenser network is due to double to two hundred machines during 1979. ${ }^{98}$ Barclays had fewer machines not only when compared with the other clearing banks but even the smaller TSB. ${ }^{99}$ At the same time, Lloyds Bank had its $100^{\text {th }}$ 'Cashpoint' operational at the Piccadilly branch in Manchester in 1981 and the $1500^{\text {th }}$ in August 1983 at the Welling, Somerset branch. ${ }^{100}$ Also in 1981, Williams \& Glyn's Bank for the first time offered electronic cash withdrawal services, using IBM 3624 machines as part of Royal Bank of Scotland's 'Cashline' network. ${ }^{101}$ Table 1 summarises the growth of installed ATMs in Britain.

\section{[Insert Table 1 around here]}

Table 1 shows data collected from three independent sources: that of Gurley combined a survey of banks and building societies (1972-1992) as well as data from the Association for Payment Clearing Services (APACS); Barrie's was based on surviving records of the British Bankers Association and APACS; while the methodology of Retail Banking Research (RBR) was not disclosed. The largest variance is observed between RBR and the other two series for the 1967 to 1985 period. Thereafter differences seem minor. It is this likely that RBR is overestimating installed capacity by considering different types of devices (such as EFT terminals). The comments that follow are thus based on Barrie's as it offers the longest series from the same source.

Data in Table 1 suggests that during the 1970s the cash dispenser fleet grew at about 20 per cent per annum. As a result a 'heritage' was at work: a fleet of combined machines installed throughout the decade with different functionality. ${ }^{102}$ This was due to the installation of new machines before disposing of old ones. The early 1980s saw a 
change in the adoption trend. A number of factors were responsible for the growth of cash dispensers with greater functionality beyond the 'tipping point' in 1980. First, a sharp increase in the number of installed ATM, followed the process of regulatory change that swept British banking in the early 1980s (a process initiated after the removal of controls for retail currency transactions in 1979 and qualitative allocation of credit, 'the corset', in 1981). During this period, large pools of people were joining the banking system as the payment of wages directly into current accounts accelerated. ${ }^{103}$ Cash dispensers were seen as a critical device for competition in retail finance, as a way to ease congestion at retail bank branches. So the combination of individual strategies and regulatory changes resulted in the growth of ATM stock accelerating: 44 per cent between 1979 and 1980, 64 per cent in 1981, 45 per cent in 1982, and 41 per cent in 1983.

A second element deals with how the process of computerisation of certain routine jobs had the potential to lower headcount and increase financial returns. Growth of installed ATM in the UK speeds up between 1979 and 1982, when it is above 60 per cent (according to the data collected by Barrie and reported in Table 1 above). At the same time, total staff in the banking sector hovers around a ten per cent annual growth between 1970 and 1979. ${ }^{104}$ There after remains stable and close to zero, until sharp decreases took place between 1990 and 2001. The ATM is not solely responsible for the drop in bank staff during the 1990s. For one, other technological applications to deliver retail financial services (such as telephone and internet banking) come into play. However, the ATM was the chief alternative to the human teller during the 1980s. Comparing the growth rates of installed cash machines and employees in banking thus seems to support Revell's idea of displaced human cashiers by ATMs took place by lowering recruitment rates rather than through redundancies during the 1980s. ${ }^{105}$

The installation of cash dispensers by building societies was a third factor adding to the growth of the ATM stock during the 1980s. Initially the number was modest. The Halifax installed six to experiment with the technology while servicing a small group of customers who had access to cheque accounts. ${ }^{106}$ The first was an IBM 3614 in 1978 at head office while five IBM 3624 were deployed in different retail branches throughout 1979. ${ }^{107}$ Alliance \& Leicester followed shortly after and also installing IBM machines. ${ }^{108}$ 
The timing of these developments is interesting because before the Building Societies Act 1986, societies were limited to accepting deposits and lending only for house purchase because they could not offer overdraft facilities. This meant that building societies and TSB had to develop on line, real time capabilities before they could offer automated withdrawals from savings accounts.

According to Barrow, the Halifax's initial encounter was useful to learn about the 'frailties' of IBM cash dispensers. ${ }^{109}$ Not surprisingly when the time came to install a large fleet in 1983, this society deployed 100 Phillips devices, that is, Diebold cash machines manufactured in the USA but distributed under license while incorporating De La Rue note dispensing capabilities.

Cash dispensers at building societies grew to 112 in 1983 and 291 in $1984 .{ }^{110}$ The trend intensified with the passing of the Building Societies Act in July 1986, which allowed the diversification of the business portfolio of the societies (while aiming to put them on the same footing with clearing banks). The number of machines then grew to 652 in 1985 ( 7 per cent of total according to data in Table 1 by Barrie), to 1,286 in 1986 (12 per cent of total) and to 2,072 in 1987 (17 per cent of total). Interestingly through this process the societies, most of which had started their computerisation on the back of IBM System 360, were no longer loyal to 'Big Blue' and purchased the much quicker, more reliable, cheaper and sophisticated NCR cash machine.

At this point some societies and other non-bank participants of retail financial markets decided there was more to be gained by creating a shared network than developing their fleet of ATMs organically. Its genesis roots to 1982 when the then head of strategic planning at Girobank, John Hardy, faced a dilemma: how to offer an increasingly popular technology to some 1.3 million customers evenly distributed through the UK. ${ }^{111}$ Investing in some 1,000 devices was out of the question. Management was only willing to purchase a couple of hundred machines while Hardy estimated that transaction volume was also low (and would not justify a four digit fleet). Partly out of necessity and partly influenced by developments in the US (namely the actions of Western Trust and Savings), Hardy found that big clearing banks were not interested in sharing their network but a small group of likeminded executives existed in other 
financial providers. In February 1985, Abbey National (the second biggest society in terms of assets), Nationwide Building Society (the third largest in terms in assets), National Giro, the Co-operative Bank, American Express and some smaller societies created LINK. ${ }^{112}$

LINK established as a joined owned company what invested in computer technology to articulate a central platform for an ATM network. The company was chaired by Hardy from its inception until he retired in 2005. The leverage gained through a shared network was self-evident as some members like the National Giro were making their first machine operational. ${ }^{113}$ Others like Abbey National, the single biggest contributor, installed 200 machines in its retail branches as well as some retail stores such as House of Fraser and 7-Eleven between February and May $1985 .{ }^{114}$ But thanks to the LINK network, Abbey's six million depositors had access to five times more $(1,000$ machines) by the end of 1986 .

A second ATM network called 'Sharing Group' built by bringing together a small group of building societies but it was short lived as it amalgamated with LINK. ${ }^{115}$ A third network was launched in March 1986. Its biggest contributor was the Woolwich Equitable Building Society (traditionally the fourth largest in terms of assets). The Woolwich had launched its 'Cashbase' dispenser in August 1985. This was for exclusive use of the 150 staff who had opened a 'Cashbase' (i.e. current) account because the pilot project for general public in Greater London and the South East (i.e. the Woolwich longest trading areas) was launched until mid-October. ${ }^{116}$ The name 'Cashbase' was chosen 'after market research among target customers' and supposed to be 'simple, memorable and which would not date. ${ }^{117}$ Cashbase machines offered a range of services namely, up to $£ 250$-a-day cash withdrawal, deposit and balance enquiry. ${ }^{118}$ The Woolwich then led six other building societies to establish 'MATRIX' (namely Leeds, National \& Provincial, Alliance, Anglia, Bradford \& Bingley and Leicester). ${ }^{119}$ This gave 8.1 million individual customers access to a network of 346 machines at the end of 1986. ${ }^{120}$ Growth for MATRIX was relatively slow as, for instance, the Woolwich reached the 100 mark until October 1987 (but had installed the first non-branch machine at J. Sainsbury's retail store in September 1988). However, in spite of the apparent disadvantage of a smaller network for the Woolwich, the rolling out of MATRIX and the 
'Cashbase' account was key to transfer customers from passbook operated deposit accounts to current accounts.

LINK then grew is size and credibility when the Halifax's 1,200 ATMs were made available to all customers of members in July 1989. However, the Halifax introduced a 50 pence 'disloyalty charge' (paid when using a non-Halifax ATM) in order to encourage Halifax own customers to use the society's ATMs whenever possible. ${ }^{121}$

Along side the creation of LINK and MATRIX, banks signed reciprocal sharing agreements. One built in around Midland, NatWest and the TSB Group. NatWest and Midland had signed an agreement through which customers could use their cards in either bank's machines to withdraw cash back in $1983 .{ }^{122}$ The TSB joined them shortly after. A second established in March 1987 by Barclays, Lloyds, Bank of Scotland and the Royal Bank of Scotland (which the West of England Building Society joined in 1988). ${ }^{123}$ The main difference between banks' sharing agreements and building societies' LINK was that banks had wired their mainframes directly rather than to a central computer acting as network switch. In contrast, LINK's central computer would act as clearing house by receiving and transmitting transactions between the member that operated the ATM and the member hosting the customer's account. However, in the early 1990s early adopters of ATM technology like Midland with a 2,000 strong network of machines in operation, abandoned sharing agreements as these proved cumbersome to manage and were found to have limited capabilities to increase their scale.

The emergence of shared ATM during the 1980s effectively meant the commoditization of retail financial services (in this case, cash withdrawal). Shared networks were also symptomatic of the end of the proprietary ATM network as a source of competitive advantage in the markets for retail finance. This strategic shift was reinforced by the presence of network externalities. These occur when the value of the network increases as new users join the network. As more members join, the network becomes more valuable to each individual user. Network externalities results in 'increasing returns', that is, as the network continues to growth, it becomes easier to attract additional users. The larger number of users in the expanded network makes 
deployment of ATM more profitable, which further enhances accessibility for existing members.

Network externalities were also found by sharing facilities at locations away from the retail bank branch and where space could be at a premium (such as hospitals, universities, airports and railway stations). For instance, NatWest's first non-branch ATM was fitted at retailer J. Sainsbury's Cristal Palace store in $1983 .{ }^{124}$ At the time this was heralded as a bank's first off-branch location. However, one of Lloyds Bank's 'Cashpoint' was operational at the retail branch at John Lewis' store in Birmingham in December 1974. ${ }^{125}$ This gave Lloyds the prestige of having operated the first cash dispenser in a non-banking site for almost 10 years before others. ${ }^{126}$

The move to non-banking sites was not immediate. As late as 1986 there was room for improving provision in retail branches (by installing second and third machines in high-usage sites) as well as enhancing reliability and convenience of installed machines (e.g. by extending on line services to $24 \mathrm{hrs}$ a day to all machines). ${ }^{127}$ Indeed, it was until 1994 that NatWest embarked on an active program to operate cash machines in non-branch locations. These included high-traffic sites at Boot the Chemist, J. Sainsbury's supermarkets and railway stations. ${ }^{128}$ Other attractive sites included hospitals, airports, petrol stations and motoring services. Barclays went even further and installed cash dispensing machines in the House of Common (1990), the House of Lords (1996) and even a ‘drive in' at Hatton Cross near Heathrow airport (1998). ${ }^{129}$

In the process of 'optimising' locations at retail branches, some cash points were closed to reciprocal agreement. NatWest, for one, kept its 'Rapid Cash Tills' (RTC) outside the agreement with Midland as late as 1986. Introduced in April 1983, two years later there were 650 RCTs in operation. The RCT was installed by NatWest mainly in Saturday opening branches as a way to service customers and keep low the number of human cashiers (who had previously been the main hurdle for Saturday opening branches). This followed from Barclays having been the first to re-introduced Saturday opening in August 1982. ${ }^{130}$ NatWest increased the number of RTCs to 900 in 1986, emphasizing its concern with making more of automation while moving away from routing paper processing. 
Although slowly, the creation of greater connectivity continued as cost containment gave way to fee income generation through interchange fees. The interchange fee (also known as terminal income), is the amount paid to the owner of an ATM by the network member bank whenever that member's cardholder uses the owner's ATM. ${ }^{131}$ Although exact figures were unavailable, between the 1980 and 2000 these fees oscillated between $25 \mathrm{p}$ and $45 \mathrm{p}$ in the UK. ${ }^{132}$ Anecdotal evidence suggests these could have been two or three times higher for transactions involving international network switches such as Visa, MasterCard, Cirrus and PLUS. At the same time, the average withdrawal almost doubled in nominal value. For NatWest the average withdrawal (in nominal value) grew from $£ 28.64$ in 1986 to $£ 47.00$ in $1997 .{ }^{133}$ It is likely this was not unique to NatWest but part of a trend where retail banking customers responded to a greater number of available machines and locations. ${ }^{134}$ For the likes of Midland, NatWest, Halifax, the TSB and Barclays, who had the largest proprietary networks and managed the most attractive off-branch sites (such as the busiest railway stations and forecourts of the largest supermarkets), reciprocity agreements were seen as a way to generate fee income. Generating fee income offered possibilities to reduce high sunk (i.e. irrecoverable) costs in setting up proprietary networks by achieving economies of scale in their running costs. The increase in the number of withdrawals provided incentives for those with larger networks to increase the number of reciprocity agreements that would make their fleet available to others.

The passing of the international standard on the physical characteristics of cards and magnetic stripe in 1978 facilitated the use of Visa and Mastercard credit cards at ATMs. This accelerated as the international franchises opened their clearing networks to EFT and synchronous retail electronic payments as well as cash withdrawals by individuals. Meanwhile, the collapse of EFPOS UK Ltd and the subsequent introductions of 'SWITCH' by Midland, NatWest and RBS while Barclays launched its 'Connect' card in June 1987, resulted in the debit card replacing payments by cheque and withdrawals using ATM cards.

The mid 1990s were rather uneventful for the ATMs. NCR's Dundee plant was the world's leading manufacturer while debit cards helped cash withdrawals to grow in popularity. However, things started to change when NatWest joined the LINK network in 
March 1997 and in the process, doubled the number of machines available to its customers to $17,622 .{ }^{135}$ From October of the same year, individual customers could also access RBS machines when the later also joined LINK. When Barclays joined the network in November 1998, 21,000 machines became available to customers of members. This expansion of LINK was followed by an attempt to impose blanket charges on ATM transactions by Barclays in 1999. The move was vilified by the press and resisted primarily by participating building societies (and notably Nationwide). All charges for cash withdrawal from current accounts were dropped and in effect, interconnectivity amongst all banks and building societies offered all retail customers a 'free to use', single national ATM network in the UK.

Also in 1998 the first 'Independent ATM Deployer' (IAD) joined LINK. Sponsored by the Woolwich and following the successful business model its main shareholder had developed in the US, Hanco broke the mould by charging a withdrawal fee (£1.50), using simple to use and inexpensive machines (Triton), and deploying in locations far away from 'free to withdraw' cash machines (such as pubs and small food stores). LINK then changed its rules to discourage sponsorships while, at the same time, open to any financial or non-financial organization who met a set of minimum requirements to become its member. By the end of 2003 Some 13 IAD came into existence. They owned or managed a total of 14,436, dispensers or about 30 per cent of installed capacity. By 2007 the IADs operated about half the fleet in the UK. However, they were responsible for less than 5 per cent of total withdrawals. Instead, the largest net acquirers of the interchange fee in LINK were those operating in the forecourts of large food retailer chains, namely two joint ventures (Tesco Personal Finance between Tesco and the RBS, and Sainsbury's Bank owned on equal share by J. Sainsbury's and the HBOS Group) and those operated by the Co-operative Bank in the retail space of stores owned by its parent (The Co-operative Group).

\section{CONCLUSION}

During the last three decades of the twentieth century, British banks replaced their ambitions to become a 'global financial supermarket' to focus on providing a diversified 
offering in UK retail finance. Building societies continued to consolidate, remained the main providers of mortgage loans and after 1986, diversified into other areas of consumer finance. The TSB amalgamated into a single provider, also diversified their business portfolio but were merged with Lloyds Bank in 1995. A key element of these processes was office mechanisation and automation of service provision on the back of computer technology. In this context, the emergence of cash dispensers and their transformation into ATM help explain a number of changes in the internal and external environment of financial intermediaries in at least five instances as follows.

First, how the process of mechanisation leading automation begins to abandon the search for greater efficiency in discrete processes (such as the accounting function). Activities begin to be redefined from first principles hoping to gain greater effectiveness in operation.

Second, the retail branch ceases to exist as the main 'production unit' and dominant point of contact with retail clients. Contrary to popular accounts, retail financial intermediaries began to change their mode of operation and retail customers' access to bank markets long before the advent of the internet. This is evident as the ATM expands the retail branch service hours, economising on labour costs and increasing customer convenience (including, for the first time, the possibility to bank at any retail branch). But ATM emerges as part of a purposeful strategy. One which from the outset aimed to blur the physical boundaries of the banking organisations while it develop retail branch and non-retail branch locations as well as being mediated by advertising and capital budgeting. The emergence of ATM networks was key in the development of information technology infrastructure (hardware, software, skills of individuals and organisational learning) which later on enabled other spaces and ways of interaction with retail customers (such as electronic funds at point of sale terminals, telephone and internet banking). Thus, the history of the ATM is much more than telling a story of a response to an 'impending need' of a more mobile population. It is a history of technical and organisational innovation.

Thirdly, there was a consistent and sustained effort of the main clearing banks to support the development of proprietary networks, even after the 'tipping point' of ATM 
adoption had been passed. This as proprietary ATM networks were perceived as a source of competitive advantage by clearing banks. As opposed to the example in the US, interconnectivity was slow to develop in Britain. Building societies and the TSB embrace ATM technology following regulatory changes and a drive to diversify throughout British financial markets. Sharing ATM networks made sense for the building societies as a way to resolve apparent scale disadvantages. At the same time, economies of scale and the potential for the machines with greater traffic to make net fee income contributions seem to have been a key incentive for those with larger proprietary networks to support the emergence of total interconnectivity. Attempts to introduce disloyalty charges failed through a combination of bad public relations and the strategies of some participants (notably the large building societies). The ATM then becomes a threshold competency in retail finance when shared networks replace proprietary networks. A move which also comprises the emergence of standardised, high volume, high margin retail financial services (i.e. commodities).

Fourthly, except for De La Rue's involvement with Barclays, during the initial period of adoption banks largely sought manufacturers that would design the new technology. Choice of functionality and manufacturer empowered individual banks to influence the evolution of design rather than having to accept technological solutions determined by manufacturers. As expected by Galbraith's 'reverse sequence, ${ }^{\text {, }}{ }^{\text {, }}$, banks proceeded with caution, committing to a limited number of machines and conducting market research (i.e. pilot test) at carefully thought-out locations. There is evidence of this behaviour in the strategies of Barclays Bank and Lloyds Bank in the 1970s but also in the 1980s around the Woolwich. Staff at banks advised manufacturers of changes in design while banks engaged advertising and finance staff to ensure success of the new offering.

But individual choice and market controlled were limited as new designs incorporate international standards (e.g. plastic cards, magnetic stripe, electronic exchange protocols). Manufacturers then offered designs with a number of modular options from where they could chose. This is clearly more evident in the processes of building societies, that is, the 'late comers' to ATM technology (which, incidentally, benefited from lower capital expenditure around a tried and tested technology). 
Finally, two important actors are missing from this story. These are the bank regulator and the monetary authority. Just as there were changes in the culture and habits of retail bank customers and within the organisational milieu of financial intermediaries, automation on the back of computer technology brought about the changes within central banks, in the money supply and in monetary control. For instance, joint ATM networks imply the creation of electronic fund payments systems protocols. Automation also had a potential impact on the balance between cash deposits and non-cash deposits as well as for preferences of cash at hand. The ATM also associates with a change from payments in cash and checks to the predominance of plastic and digital payments on the back of credit and debit cards. For most of the period examined in this paper, the Bank of England assumed the roles of bank regulator and shared that of monetary authority in Britain. As had been the case in the US, 'it would be difficult to overestimate the influence of regulatory bodies and laws in the character and practices of the Financial Sector. ${ }^{137}$ When and how did the Bank of England became interested in the ATM and the emergence of EFPS in retail financial markets has yet to be documented.

\section{ACKNOWLEDGEMENTS}

This research proceeded with partial financial support from the British Academy (LRG41806) and the Charles Babbage Institute (Arthur Norberg Travel Fund). Helpful research assistance of Abass Barrie when at London South Bank, Robert Reid and Claudia Reese at Leicester, Ian Ormerod's access to his personal collection on the NCR Corporation as well as Karen Sampson (Lloyds TSB Archives), Nicholas Webb (Barclays Group Archive), Philip Winterbottom and Derek Hammond (The Royal Bank of Scotland Group Archives) and Tom Misa, Jeff Yost and Stephanie Horowitz (Charles Babbage Institute) is much appreciated. So are helpful comments from Jeremy Attack, Mark Billings, Richard Coopey, Jamie McAndrews, participants at the Business History Conference, (Cleveland, 2007), staff seminars at the University of Missuouri and Stuart Winer and his staff at the Payment Systems Research Group at the Federal Reserve Bank of Kansas City. The usual caveats apply. 


\section{References}

Ackrill, M., and L. Hannah. Barclays: The Business of Banking 1690-1996. Cambridge: Cambridge University Press, 2001.

Barrie, Abass. "The Impact of Information Technology on Uk Banking: The Case of Automated Teller Machines." MSc International Finance and Banking, London South Bank University, 2006.

Barrow, Richard. Fifty More Years of the Halifax 1953-2003. Halifax: HBOS and Richard Barrow, 2006.

Bátiz-Lazo, Bernardo, and Mark Billings. "In Search of a Winning Strategy: A Case Study of Strategic Change at the Woolwich Equitable Building Society (195070)." In Fifth Accounting History International Conference. Banff, 2007.

Bátiz-Lazo, Bernardo, and Trevor Boyns. "Automation and Management Accounting in British Manufacturing and Retail Financial Services, 1945-68." Paper presented at the Information Systems and Technology in Organisations and Society, Universitat Pompeu Fabra, Barcelona 2003.

Bátiz-Lazo, Bernardo, and Nurdilek Hacialioglu. "Barclaycard: Still the King of Pla\$Tic?" In Exploring Corporate Strategy: Text and Cases, edited by Gerry Johnson, Kevan Scholes and Richard Withington, 892-906. Harlow: Prentice Hall / Financial Times, 2005.

Bátiz-Lazo, Bernardo, and J. Carles Maixé-Altes. "Organisational Change and the Computerisation of British and Spanish Savings Banks, Circa 1950-1985." Paper presented at the Business History Conference, Sacramento 2008.

Bátiz-Lazo, Bernardo, and Claudia Reese. "Is the Future of the Atm Past?" Paper presented at the Association of Business Historians Annual Conference, Birmingham 2008.

Bátiz-Lazo, Bernardo, and Robert Reid. "Evidence from the Patent Record on the Development of Cash Dispensers and Atm Technology." Paper presented at the IEEE History of Telecommunications Conference, Paris 2008. . "Who Invented the Atm? Challenging the Conventional Wisdom." Paper presented at the Association of Business Historians Annual Conference, Birmingham 2008.

Bátiz-Lazo, Bernardo, and Peter Wardley. "Banking on Change: Information Systems and Technologies in Uk High Street Banking, 1919-1969." Financial History Review (2007).

. "Banking on Change: Information Systems and Technologies in Uk High Street Banking, 1919-1969." Financial History Review 14, no. 2 (2007): 177-205.

Bátiz-Lazo, Bernardo, and Douglas Wood. "An Historical Appraisal of Information Technology in Commercial Banking." Electronic Markets - The International Journal of Electronic Commerce \& Business Media 12, no. 3 (2002): 192-205.

Bonin, Hubert. "The Development of the Use of Accounting Machines in French Banks from the 1920s to the 1960s." Accounting, Business and Financial History 14, no. 3 (2004): ?? 
Booth, Alan E. "British Retail Banks, 1955-70: A Case of 'Americanisation'?" In Americanisation in Twentieth Century Europe: Business, Culture, Politics, edited by M. Kipping and N. Tirasoo. Lille: Université Charles de Gaulle, 2001. . "Technical Change in Branch Banking at the Midland Bank, 1945-75." Accounting, Business and Financial History 14, no. 3 (2004): 277-300.

Ceruzzi, Paul E. A History of Modern Computing. 2nd ed. Cambridge MA and London: The MIT Press, 2003.

Coombs, Rod, David Knights, and Hugh Willmott. "Culture, Control and Competition: Towards a Conceptual Framework for the Study of Information in Organizations." Organization Studies 13, no. 1 (1992): 51-72.

Coopey, Richard. "A Passing Technology: The Automated Teller Machine." In Wiring Prometheus: Globalisation, History and Technology, edited by Peter Lyth and Helmuth Trischler. Aarhus: Aarhus University Press, 2004.

Cortada, James W. The Digital Hand, Vol. 2. New York: Oxford University Press, 2006.

Davies, G. Building Societies and Their Branches: A Regional Economic Survey. London: Fianey \& Co., 1981.

Galbraith, John K. The New Industrial State. Edited by Sean Wilentz. 4th (2005) Foreword bJames K Galbraith ed, The James. Princeton and Oxford: Princeton University Press, 1967.

Gourley, Adrian Robert. "The Diffusion of Process Innovation in the Uk Financial Sector: An Empirical Analysis of Automated Teller Machine (Atm) Diffusion." $\mathrm{Ph}$ D, Loughborough University, 1999.

Haigh, Thomas. "'a Veritable Bucket of Facts': Origins of the Data Base Management System, 1960-1980." ACM SIGMOD Record 35, no. 2 - June (2006): 73-88.

Hayashi, Fumiko, Richard J. Sullivan, and Stuart E. Weiner. A Guide to the Atm and Debit Card Industry. Kansas City MO: Federal Reserve Bank of Kansas City, 2003. . A Guide to the Atm and Debit Card Industry - an Update. Kansas City MO: Federal Reserve Bank of Kansas City, 2006.

Hopkins, Deborah Ann. "Factors Affecting the Adoption of Automated Teller Machines, Direct Deposit of Paychecks and Partial Direct Deposit to Savings Where Available." Ohio State University, 1986.

Hopton, David. Electronic Fund Transfer Systems : The Issues and Implications. Cardiff: University of Wales Press, 1979.

Howells, J. , and J. Hine. Innovative Banking: Competition and Management of the Network Technology. Cornwall: TJ Press (Padstow), 1993.

Kirkman, P. Electronic Funds Transfer System: The Revolution of Cashless Banking and Payment Methods. New York: Basil Blackwell Inc., 1987.

Kotter, James P. A Force for Change: How Leadership Differs from Management. London: Free Press, 1990.

Lane, Sarah Julia. "Entry and Industry Evolution in the Atm Manufacturers' Market." Ph.D. dissertation, Stanford University, 1989.

Lee, Eun-Ju. "Consumer Adoption and Diffusion of Technological Innovations: A Case of Electronic Banking Technologies." Ph.D. dissertation, The University of Tennessee, 2000. 
Lozano, Marvin Francis. "The Diffusion and Adoption of a Technical Innovation: The Automated Teller Machine." The University of Arizona, 1987.

Martin, Graeme, and Tom Riddell. "The Wee Oufit That Decked Ibm: 'Manufacturing' Strategic Change and Leadership in 'Cash Dispensing'." Strategic Change 5, no. 3 (1996): 3-25.

McAndrews, James J. "Automated Teller Machines Network Pricing - a Review of Literature." Review of Network Economics 2, no. 2 (2003): 146-58.

. "The Evolution of Shared Atm Networks." Federal Reserve Bank of Philadelphia Business Review May/June (1991): 3-16.

McKenney, James L., and Amy Weaver Fisher. "Manufacturing the Erma Banking System: Lessons from History." IEEE Annals of the History of Computing 15, no. 4 (1993): 7-26.

Peffers, Kenneth Gordon. "Information Technology Impact on Performance: An Investigation of Investments in Automated Teller Machines." Ph.D. dissertation, Purdue University, 1991.

Revell, J. R. S. Banking and Electronic Fund Transfers. Paris: Organization for Economic Co-operation and Development, 1983.

Richardson, Denis W. Evolution of an Electronic Funds-Transfer System. Cambridge MA: The MIT Press, 1970.

Rosenbloom, Richard S. "Leadership, Capabilities, and Technological Change: The Transformation of Ncr in the Electronic Era." Strategic Management Journal 21 (2000): 1083-103.

Sienkiewicz, Stan. "The Evolution of Eft Networks from Atms to New on-Line Debit Payment Products." In Discussion Paper Payments Cards Centre - Federal Reserve Bank of Philadelphia. Philadelphia, 2002.

Vázquez-Alanís, Gregorio. "Atm Adoption by Banks in Mexico:Did It Lead to Performance and Network Effects?", Instituto Tècnologio de Estudios Superiores de Monterrey, 2007.

Walker, D. "Electronic Funds Transfer Cost Models and Pricing Strategies." Journal of Economics and Business Fall (1980): ??

Wardley, Peter. "The Commercial Banking Industry and Its Part in the Emergence and Consolidation of the Corporate Economy in Britain before 1940." Journal of Industrial History 3, no. 2 (2000): 71-97.

Yavitz, Boris. Automation in Commercial Banking. New York: The Free Press, 1967. 


\section{Notes}

${ }^{1}$ Boris Yavitz, Automation in Commercial Banking (New York: The Free Press, 1967), Hubert Bonin, "The Development of the Use of Accounting Machines in French Banks from the 1920s to the 1960s," Accounting, Business and Financial History 14, no. 3 (2004), James L. McKenney and Amy Weaver Fisher, "Manufacturing the Erma Banking System: Lessons from History," IEEE Annals of the History of Computing 15, no. 4 (1993). Peter Wardley, "The Commercial Banking Industry and Its Part in the Emergence and Consolidation of the Corporate Economy in Britain before 1940," Journal of Industrial History 3, no. 2 (2000), Alan E. Booth, "British Retail Banks, 1955-70: A Case of 'Americanisation'?," in Americanisation in Twentieth Century Europe: Business, Culture, Politics, ed. M. Kipping and N. Tirasoo (Lille: Université Charles de Gaulle, 2001),__, "Technical Change in Branch Banking at the Midland Bank, 1945-75," Accounting, Business and Financial History 14, no. 3 (2004), Bernardo Bátiz-Lazo and Mark Billings, "In Search of a Winning Strategy: A Case Study of Strategic Change at the Woolwich Equitable Building Society (1950-70)," in Fifth Accounting History International Conference (Banff: 2007), Bernardo Bátiz-Lazo and Trevor Boyns, "Automation and Management Accounting in British Manufacturing and Retail Financial Services, 1945-68" (paper presented at the Information Systems and Technology in Organisations and Society, Universitat Pompeu Fabra, Barcelona, 2003), Bernardo BátizLazo and Peter Wardley, "Banking on Change: Information Systems and Technologies in Uk High Street Banking, 1919-1969," Financial History Review (2007), Bernardo Bátiz-Lazo and Douglas Wood, "An Historical Appraisal of Information Technology in Commercial Banking.," Electronic Markets - The International Journal of Electronic Commerce \& Business Media 12, no. 3 (2002).

${ }^{2}$ Bátiz-Lazo and Wood, "An Historical Appraisal.", Denis W. Richardson, Evolution of an Electronic Funds-Transfer System (Cambridge MA: The MIT Press, 1970).

${ }^{3}$ Paul E. Ceruzzi, A History of Modern Computing, 2nd ed. (Cambridge MA and London: The MIT Press, 2003), 80.

${ }^{4}$ Richardson, Evolution of an Electronic Funds-Transfer System.. Other efforts include James J. McAndrews, "The Evolution of Shared Atm Networks," Federal Reserve Bank of Philadelphia Business Review May/June (1991)., Stan Sienkiewicz, "The Evolution of Eft Networks from Atms to New on-Line Debit Payment Products," in Discussion Paper Payments Cards Centre - Federal Reserve Bank of Philadelphia (Philadelphia: 2002)., Fumiko Hayashi, Richard J. Sullivan, and Stuart E. Weiner, A Guide to the Atm and Debit Card Industry - an Update (Kansas City MO: Federal Reserve Bank of Kansas City, 2006). and (2005). Others who have written on the emergence and diffusion of ATM in the US include doctoral dissertations by Deborah Ann Hopkins, "Factors Affecting the Adoption of Automated Teller Machines, Direct Deposit of Paychecks and Partial Direct Deposit to Savings Where Available" (Ohio State University, 1986)., Marvin Francis Lozano, "The Diffusion and Adoption of a Technical Innovation: The Automated Teller Machine" (The University of Arizona, 1987)., Sarah Julia Lane, "Entry and Industry Evolution in the Atm Manufacturers' Market" (Ph.D. dissertation, Stanford University, 1989)., Kenneth Gordon Peffers, "Information Technology Impact on Performance: An Investigation of Investments in Automated Teller Machines" (Ph.D. dissertation, Purdue University, 1991). and Eun-Ju Lee, "Consumer Adoption and Diffusion of Technological Innovations: A Case of Electronic Banking Technologies" (Ph.D. dissertation, The University of Tennessee, 2000).

${ }^{5}$ David Hopton, Electronic Fund Transfer Systems : The Issues and Implications (Cardiff: University of Wales Press, 1979)., P. Kirkman, Electronic Funds Transfer System: The Revolution of Cashless Banking and Payment Methods (New York: Basil Blackwell Inc., 1987). and J. Howells and J. Hine, Innovative Banking: Competition and Management of the Network Technology (Cornwall: TJ Press (Padstow), 1993).. ${ }^{6}$ Richard Coopey, "A Passing Technology: The Automated Teller Machine," in Wiring Prometheus: Globalisation, History and Technology, ed. Peter Lyth and Helmuth Trischler (Aarhus: Aarhus University Press, 2004). and Abass Barrie, "The Impact of Information Technology on Uk Banking: The Case of Automated Teller Machines" (MSc International Finance and Banking, London South Bank University, 2006).

${ }^{7}$ M. Ackrill and L. Hannah, Barclays: The Business of Banking 1690-1996 (Cambridge: Cambridge University Press, 2001), 214 and 332-4.

${ }^{8}$ Gregorio Vázquez-Alanís, "Atm Adoption by Banks in Mexico:Did It Lead to Performance and Network Effects?" (Instituto Tècnologio de Estudios Superiores de Monterrey, 2007).. 
9 James J. McAndrews, "Automated Teller Machines Network Pricing - a Review of Literature," Review of Network Economics 2, no. 2 (2003).

${ }^{10}$ Rod Coombs, David Knights, and Hugh Willmott, "Culture, Control and Competition: Towards a Conceptual Framework for the Study of Information in Organizations," Organization Studies 13, no. 1 (1992).

${ }^{11}$ J. R. S. Revell, Banking and Electronic Fund Transfers (Paris: Organization for Economic Co-operation and Development, 1983), 42. and McAndrews, "The Evolution of Shared Atm Networks," 4.

${ }^{12}$ Bernardo Bátiz-Lazo and Claudia Reese, "Is the Future of the Atm Past?" (paper presented at the Association of Business Historians Annual Conference, Birmingham, 2008).

${ }^{13}$ Coopey, "A Passing Technology: The Automated Teller Machine."

${ }^{14}$ Ibid., 175.

${ }^{15}$ Revell, Banking and Electronic Fund Transfers, 42.

${ }^{16}$ Bernardo Bátiz-Lazo and J. Carles Maixé-Altes, "Organisational Change and the Computerisation of British and Spanish Savings Banks, Circa 1950-1985" (paper presented at the Business History Conference, Sacramento, 2008).

${ }_{17}^{17}$ Ceruzzi, A History of Modern Computing, 80.

${ }^{18}$ Sienkiewicz, "The Evolution of Eft Networks from Atms to New on-Line Debit Payment Products."

${ }^{19}$ Wardley, "The Commercial Banking Industry.", Bátiz-Lazo and Wood, "An Historical Appraisal.", Bátiz-Lazo and Wardley, "Banking on Change: Information Systems and Technologies in Uk High Street Banking, 1919-1969." Note that by 1911, a process of amalgamation left some 80 per cent of deposits in the hands of five banks (Midland, Barclays, Lloyds, Westminster, National and Provincial). These plus some six others controlled access to the cheque clearing system. Hence the name, clearing banks. Amalgamations also had the effect of providing clearing banks with a national web of offices and retail bank branches. Building societies are mutual organizations which for most of their history specialized in deposit taking and mortgage provision. Societies used agents and developed retail branches more organically than clearing banks. Other participants in British retail finance included insurance companies, trustee savings banks and hire purchase companies. After 1970s, these were joined by the National Giro Bank and the Co-operative Bank.

${ }^{20}$ Bank of England Archive, C54/10 Chief Cashiers Duplicate Letters, C.L.C.B. Meeting of the $2^{\text {nd }}$ July, 30 Jun. 1964; Webb, C. "Never on a Saturday", The Times, June 28, 1969, p. 8; Thomas, A. "Problems ahead as Saturday banking ends", The Times, June 28, 1969, p. 11.

${ }^{21}$ G. Davies, Building Societies and Their Branches: A Regional Economic Survey (London: Fianey \& Co., 1981). and Bátiz-Lazo and Billings, "In Search of a Winning Strategy: A Case Study of Strategic Change at the Woolwich Equitable Building Society (1950-70)."

${ }^{22}$ Bátiz-Lazo and Wardley, "Banking on Change: Information Systems and Technologies in Uk High Street Banking, 1919-1969."

${ }^{23} \mathrm{http}$ ://americanhistory.si.edu/collections/comphist/wetzel.htm (accessed 16-Apr-07).

${ }^{24}$ McAndrews, "The Evolution of Shared Atm Networks," 5. and Fumiko Hayashi, Richard J. Sullivan, and Stuart E. Weiner, A Guide to the Atm and Debit Card Industry (Kansas City MO: Federal Reserve Bank of Kansas City, 2003).

${ }^{25}$ http://en.wikipedia.org/wiki/Automated teller_machine (accessed 16-Apr-07) and http://web.mit.edu/invent/iow/simjian.html (accessed 16-Apr-07).

${ }^{26}$ Bernardo Bátiz-Lazo and Robert Reid, "Evidence from the Patent Record on the Development of Cash Dispensers and Atm Technology" (paper presented at the IEEE History of Telecommunications Conference, Paris, 2008), _— , "Who Invented the Atm? Challenging the Conventional Wisdom." (paper presented at the Association of Business Historians Annual Conference, Birmingham, 2008).

27 'Universal Match Maps Acquisition', The New York Times, 22-Mar-61

28 'Machine Accepts Cash Deposits', The New York Times, 12-Apr-61.

29 'Instant Cash via Credit Cards', ABA Banking Journal, January 1967, p. 99.

30 Bátiz-Lazo and Reid, "Evidence from the Patent Record on the Development of Cash Dispensers and Atm Technology", _ _ "Who Invented the Atm? Challenging the Conventional Wisdom.".

${ }^{31}$ Nye, Peggy (1967) 'Instant Case at Enfield', Spread Eagle, vol. 42 (Aug), p. 326.

${ }^{32}$ Nye, Peggy (1967) 'Instant Case at Enfield', Spread Eagle, vol. 42 (Aug), p. 327.

${ }^{33}$ Nye, Peggy (1967) 'Instant Case at Enfield', Spread Eagle, vol. 42 (Aug), p. 328. 
${ }^{34}$ In 1970 the Westminster Bank and the National Provincial Bank merged into National Westminster Bank (NatWest). The amalgamation also considered the District Bank, which had been acquired by the National Provincial Bank in 1962 but allowed to operate under its own name.

${ }^{35}$ The Royal Bank of Scotland Group Archives (hereafter RBSGA) - WES/693, Westminster Bank, press release 31 July 1967.

${ }^{36}$ RBSGA - WES/963, Westminster bank, 'Technical Information, Chubb \& Son's Lock \& Safe Co Ltd', 1967.

${ }^{37}$ Personal communication (e-mail), Nicholas Webb, Barclays Bank Archive, 'ATM Paper', 19-Jun-07.

${ }^{38}$ RBSGA - DIS /641, District Bank, photographs of Piccadilly branch cash dispenser on first day of use, 5 January 1968.

${ }^{39}$ RBSGA - RB/150/2, The Royal Bank of Scotland, staff newspaper 'Newsline', February 1993.

According to this article the actual date of operation was 28 December 1967: 'The first cash machine soon proved a hit!'.

${ }^{40}$ The other exception being the Bank of Scotland who also adopted De La Rue's DACS in 1971 (and called it 'Scotcash') thanks to the shareholding links with Barclays.

41 'Round-the-clock cash service', Barclays Bulleting, 1968, vol. 12 (Autumn).

${ }^{42}$ Nye, Peggy (1967) 'Instant Case at Enfield', Spread Eagle, vol. 42 (Aug), p. 328.

${ }^{43}$ BGA - Automation Committee Minutes: 80/2709, 2.e On line Cash Dispensers, 5-Mar-73.

${ }^{44}$ RBSGA - DR/418, The Royal Bank of Scotland, Drummonds Branch, leaflet '24 hour cash service', circa 1968.

${ }^{45}$ RBSGA - WES/963, Westminster bank, 'Technical Information, Chubb \& Son's Lock \& Safe Co Ltd', 1967.

${ }^{46}$ RBSGA - WES/693, Westminster Bank, press release, 31 July 1967.

${ }^{47}$ Ackrill and Hannah, Barclays, 328-9..

${ }^{48}$ RBSGA - DR/418, The Royal Bank of Scotland, Drummonds Branch, leaflet '24 hour cash service', circa 1968.

${ }^{49}$ Coopey, "A Passing Technology: The Automated Teller Machine," 176-7, Bernardo Bátiz-Lazo and Nurdilek Hacialioglu, "Barclaycard: Still the King of Pla\$Tic?," in Exploring Corporate Strategy: Text and Cases, ed. Gerry Johnson, Kevan Scholes, and Richard Withington (Harlow: Prentice Hall / Financial Times, 2005), 893.

${ }^{50}$ Nye, Peggy (1967) 'Instant Case at Enfield', Spread Eagle, vol. 42 (Aug), p. 326.

${ }^{51}$ Certainly the account that predominates in the US popular press see http://www.atmmarketplace.com/article.php?id=1339 (accessed 18-Apr-07); http://money.cnn.com/magazines/fortune/fortune_archive/2004/07/26/377172/index.htm (accessed 18-Apr07); a brief oral history of Dan Wetzel at http://americanhistory.si.edu/collections/comphist/wetzel.htm (accessed 16-Apr-07).

${ }^{52}$ By 2007, NCR had about 70 per cent of the world ATM installations. In Britain it was about 90 per cent. Personal communication (email), Ian Omrod, Ex-Officio Historian of NCR, 11-Apr-2007. Company documents claimed that by 1981 the ATM had made over 1.7 billion transactions in the US alone and NCR was the world leading manufacturer (The History of NCR, p. 107).

${ }^{53}$ Interview with Jim Adamson, former CEO of NCR Dundee, 18 June 2008.

${ }^{54}$ RBSGA - DR/418, The Royal Bank of Scotland, Drummonds Branch, leaflet '24 hour cash service', circa 1968.

${ }^{55}$ Bernardo Bátiz-Lazo and Peter Wardley, "Banking on Change: Information Systems and Technologies in Uk High Street Banking, 1919-1969," Financial History Review 14, no. 2 (2007).

${ }^{56}$ Bátiz-Lazo and Reid, "Who Invented the Atm? Challenging the Conventional Wisdom."..

${ }^{57}$ The bank had dispensers installed at branches in the West End of London (3); the Home Counties (9); and the Birmingham area (12) ('On line' Ready Cash, Lloyds Bank News, Sep 1970, Front Page).

58 “'On line” Ready Cash', Lloyds Bank News, No. 45 Sep 1970, Front Page. Italics in the original.

59 'Counter Revolution', Lloyds Bank News, No. 50 Feb 1971, p. 5.

${ }^{60}$ Thomas Haigh, "'a Veritable Bucket of Facts': Origins of the Data Base Management System, 19601980," ACM SIGMOD Record 35, no. 2 - June (2006).

${ }^{61}$ Ackrill and Hannah, Barclays, 322-4.

${ }^{62}$ Unless otherwise stated, this paragraph borrows freely from "Bank scores "first" in branch computer linkup', Counter Revolution', Lloyds Bank News, No. 50 Feb 1971, p. 5. 
${ }^{62}$ Unless otherwise stated, this paragraph borrows freely from 'Bank scores "first" in branch computer linkup', Lloyds Bank News, No. 47 Nov 1970, Front Page.

63 'Bank scores "first”' in branch computer link-up', Lloyds Bank News, No. 47 Nov 1970, Front Page.

64 'New 'robot' cashier to help staff', Lloyds Bank News, No. 54 Jun 1971, Front Page.

${ }^{65}$ Idem.

66 'Run-up begins for cash point launch', Lloyds Bank News, No. 69 Sep 1972, Front Page.

67 'New 'robot' cashier to help staff', Lloyds Bank News, No. 54 Jun 1971, Front Page. However, the team at Speytec (which by that time had moved to be a subsidiary of Burroughs in the UK) already had a couple of years experience in developing a cash machine operated by a card and magnetic stripe Bátiz-Lazo and Reid, "Evidence from the Patent Record on the Development of Cash Dispensers and Atm Technology".. ${ }^{68}$ Idem.

69 'Run-up begins for cash point launch', Lloyds Bank News, No. 69 Sep 1972, Front Page.

${ }^{70}$ Unless otherwise stated, this paragraph borrows freely from BGA - Automation Committee Minutes: 80/2709, 2.e On line Cash Dispensers, 5-Mar-73.

${ }^{71}$ BGA - Automation Committee Minutes: 80/2709, C Other Items, 25-Sep-74.

${ }^{72}$ Financial Times, 25 May 1975.

73 Ackrill and Hannah, Barclays, 336..

${ }^{74}$ BGA, 'Barclays Fact Sheet - Cash Machines', undated. Note compiled by Barclays Group Archives.

${ }^{75}$ RBSGA - NWB/914/2, National Westminster Bank, press release, 9 Sep 1975.

${ }^{76}$ RBSGA - unpublished research note compiled by Group Archives. This makes a reference that perhaps Barclays made available to the public a similar external machine shortly before NatWest

${ }^{77}$ Walker D. Walker, "Electronic Funds Transfer Cost Models and Pricing Strategies," Journal of Economics and Business Fall (1980). estimated that in 1974, the fixed cost of purchasing and installing an ATM was between $\$ 25,000$ and $\$ 30,000$ while $\$ 200,000$ should be added to consider operating costs of armored car services and data processing. At the time the Westminster Bank had 6,000 customers with cash cards and nine Chubb machines (RBSGA - unpublished research note compiled by Group Archives). That is, an average of 667 customers per machine. The Westminster would achieve economies of scale at Walker's rate of 44 thousand transactions per machine per month if each of the Westminster's customers made, on average, 1.2 withdrawals per week.

${ }^{78}$ Personal communication, Ian Ormerod (19-Apr-07) and RBSGA - NWB/914/2 NatWest press release, 9 Sep 1975.

${ }^{79}$ RBSGA - NWB/19/101, National Westminster Bank, internal ciruclar DB 56 - 1975 (G.D. Burnett, General Manager, Domestic Banking Division), 29-May-1975.

${ }^{80}$ Idem.

${ }^{81}$ Burroughs Corp., Annual Report and Accounts, 1977, p. 23. Charles Babbage Institute holdings (henceford CBI), Burroughs Corp., Press Releases (90:72, Box 10, Folder 6, Item 60, 16-Nov-1976).

${ }^{82}$ Burroughs Corp., Annual Report and Accounts, 1978, p. 7. CBI (90:72), Burroughs Corp., Press Releases (Box 10, Folder 14, Item 45, 08-May-1980).

${ }^{83}$ Unless otherwise stated this paragraph borrows freely from CBI (90:72), Burroughs Corp., Press

Releases (Box 10, Folder 1, Item 12, 18-Feb-1975).

${ }^{84}$ RBSGA - NWB/914/2, National Westminster Bank, press release, 09 Sep 1975.

${ }^{85}$ NCR Corporation Annual Report and Accounts, 1975, p. 2. See further James P. Kotter, A Force for Change: How Leadership Differs from Management (London: Free Press, 1990).; Graeme Martin and Tom Riddell, "The Wee Oufit That Decked Ibm: 'Manufacturing' Strategic Change and Leadership in 'Cash Dispensing'," Strategic Change 5, no. 3 (1996).; Richard S. Rosenbloom, "Leadership, Capabilities, and Technological Change: The Transformation of Ncr in the Electronic Era," Strategic Management Journal 21 (2000).

86 "Cash Advance": The History of NCR in Scotland 1946-1996, Dundee: NCR Corp., p. 28.

${ }^{87}$ NCR Corporation, Annual Report and Accounts, 1978.

88 "Cash Advance", p. 28.

${ }^{89}$ NCR Pocket Digest, p. 36

${ }^{90}$ Kotter, A Force for Change: How Leadership Differs from Management, 27.

${ }^{91}$ Chubb \& Son's Lock and Safe Company Group Annual Report and Accounts, 1974, p. 5.

${ }^{92}$ Chubb \& Son's Lock and Safe Company Group Annual Report and Accounts, 1977, p. 11. 
${ }^{93}$ The cash register business based in Hollingbury near Brighton was sold shortly after amalgamation while manufacturing of cash dispensing technology moved to Chubb Integrated Systems. The latter was eventually renamed Chubb Security Installations or CSI. CSI was subsequently divested in 2000 and acquired by Gunnebo Group (of Sweden). Since then it has traded as CSI Gunnebo and retained some related products such as Armapod Plus, Citypod and Cityroom; all of which were designed to house the ATM machines and to protect those individuals who replenish or service them and may be at risk from a physical assault or armed attack whilst doing so. Source: Personal Communication (email), Jane Garland, Marketing Communications Manager, Chubb Fire Limited (A UTC Fire \& Security Company), 10-Apr-07; Personal Communication Alan Jacques (email), Design and Engineering Manager, Gunnebo CSI (01-May2007); http://www.csisec.com/company profile history.htm (accessed 16-Apr-07) and http://www.chubb.co.uk/chserver/request/setTemplate:singlecontent/contentTypeA/webdoc/contentId/646/ navId/00000b000 (accessed 16-Apr-07).

${ }^{94}$ Investor's Chronicle, 3 March 1978. Note that in 1970, Chubb purchased ICC Machines Ltd., a specialist in devices for counting, issuing and changing coins.

${ }^{95}$ Chubb \& Son's Lock and Safe Company Group Annual Report and Accounts, 1980, 1981 and 1982.

${ }^{96}$ Cash Advance (1996, p. 37) quotes and briefly discusses the following heading that appeared in Fortune magazine: 'The wee outfit who decked IBM'.

${ }^{97}$ BGA, 'Barclays Fact Sheet - Cash Machines', undated. Note compiled by Barclays Group Archives.

${ }_{98}$ Barclays Bank Annual Report and Accounts, 1978, p.43.

${ }^{99}$ Ackrill and Hannah, Barclays, 336..

${ }^{100}$ Lloyds TSB Archive, Index cards on ATM.

${ }^{101}$ RBSGA - WG/133, Williams \& Glyn's Bank, folder 'New branch terminals', c.1980. The move is not to be considered as an independent ATM network. The Royal Bank of Scotland (RBS) and Williams \& Glyn's were part of the same banking group but trading independently. As part of RBS's expansion after World War I, it acquired various small English banks, including London based Drummonds Bank in 1924; and William Deacon's Bank based in North West England in 1930; and Glyn, Mills and Co in 1939. The latter two were merged in 1970 to form Williams and Glyn's Bank; and later rebranded as the Royal Bank of Scotland in 1985.

${ }^{102}$ James W. Cortada, The Digital Hand, Vol. 2 (New York: Oxford University Press, 2006), $35 .$.

${ }^{103}$ Bátiz-Lazo and Reese, "Is the Future of the Atm Past?", 4.

${ }^{104}$ Association for Payment Clearing Services (APACS), Yearbook of Payment Statistics, APACS

Statistical Unit (London, several issues).

${ }^{105}$ Revell, Banking and Electronic Fund Transfers, 67.

${ }^{106}$ Prior to the amalgamation of the Halifax Equitable and Halifax Permanent in 1928 both had their own banks. This resulted in a legacy of 11 thousand deposit cheque accounts (DAC) serviced through four branches (Halifax, Hudersfield, Bradford and Sheffield). These accounts enabled the deployment of a small number of IBM3624 cash machines. Source: Interview Richard Barrow, Halifax (19- May-08) and Richard Barrow, Fifty More Years of the Halifax 1953-2003 (Halifax: HBOS and Richard Barrow, 2006), pp. 72 and 82.

${ }^{107}$ Ibid., 72.

${ }^{108}$ Disregarding the small experiment by the Halifax, Alliance \& Leicester has a claim to be the first in the field. It is not clear whether these were IBM3614 or IBM3624. Source: Personal Communication (email), Nigel Hardman, Group Archives, Alliance \& Leicester (03-May-07).

${ }^{109}$ Barrow, Halifax, 82.

${ }^{110}$ Note that the survey by Gourley Adrian Robert Gourley, "The Diffusion of Process Innovation in the Uk Financial Sector: An Empirical Analysis of Automated Teller Machine (Atm) Diffusion" (Ph D, Loughborough University, 1999), 4.46. attributes the first ATM to the Halfiax until 1983 and claims the Alliance \& Leicester had 16 in operation in 183 (to a total of 17 for all building societies).

${ }^{111}$ Unless otherwise stated the reminder of this paragraph borrows freely from an interview with John Hardy, former CEO of LINK, London (21-Nov-07).

112 "Building society in cash link", The Times, 16-Feb-85, pg. 3, Issue 62064, col. A.

${ }_{113}$ Personal Communication (email), Nigel Hardman, Group Archives, Alliance \& Leicester (03-May-07).

114 The first machine installed in a British rail station took place in 1970, when a cash dispenser became operational in London's Victoria Station by the National Provincial Bank (shortly before its brand name 
changed to National Westminster Bank or NatWest). This was, however, within the premises of the bank's Victoria branch. Source: RBSGA - NW/B1239, National Westminster Bank, photograph of a member of staff using the cash dispenser at Victoria Station Branch of National Westminster Bank.

${ }^{115}$ Interview with John Hardy, former CEO of LINK, London (21-Nov-07).

116 'Cashbase: switch-on at Head Office', Woolwich World vol. 8, no. 8, p. 01 (Aug 1985).

117 'Cashbase set for launch later in the year', Woolwich World vol. 8, no. 7, p. 01 (Jul 1985).

${ }^{118}$ Renewing the offer of envelope deposits by Cashbase in the mid-1980s was interesting. As noted above this was the central feature of the Simjian machine in 1960 and had been pushed by US banks along cash dispensing given their interest in capturing core deposits during the 1970s. In the UK, Barlcays explored the possibility of accepting envelop deposits via cash dispensers as early 1976, but found that transactions involving withdrawals were ten times more frequent. Indeed, in December 1976 the Management Services Department reported that 43,670 Barclaybank cards had been issued in the four weeks to $27^{\text {th }}$ of November, while there had been 6,983 withdrawals (at an average of $£ 21$ per withdrawal) there were only 663 deposits (average amount not disclosed). Although Barclays eventually discontinued the service in the 1970s, it was reintroduced as 'Express Deposit' with new Barclaybank machines using 'Barclay's Connect' cards in 1991. Source: BSA - Automation Committee Minutes: 415/156 - 'Use of Machines', 15-Dec-76; Personal Communication (email), Nicholas Webb, Barclays Group Archives, (23-Jun-07).

119 'Countdown to Cashbase', Woolwich World vol. 8, no. 7, p. 03 (Jul 1985).

${ }^{120}$ Initially there were 120 cash dispensers. These were expected to increase to 400 in number by the end of the year and to 1,000 installed machines within two years. See further 'Scotland joins Cashbase link',

Woolwich World vol. 9, no. 10, p. 01 (Sep 1986) and 'Matrix gets off to a flyer', Woolwich World vol. 9, no. 03, p. 01 (Mar 1986).

${ }^{121}$ Barrow, Halifax, 98.

${ }^{122}$ RBSGA - unpublished research note compiled by Group Archives.

${ }^{123}$ BGA, 'Barclays Fact Sheet - Cash Machines', undated. Note compiled by Barclays Group Archives. However, an internal document also compiled by Barclays Group Archives claims 'Barclays joins a consortium of five banks sharing ATM facilities' in April 1983.

${ }^{124}$ RBSGA - NWB/914/12, NatWest, news release 288/98, 1 December 1988.

${ }^{125}$ Lloyds TSB Archive, Index cards on ATM.

${ }^{126}$ Lloyds Bank acquired the in-store branches of Lewis' and Selfridges in the early 1970s. It was evident from the staff magazine (Lloyds Bank News) these were operated as an integral part of the bank rather than at arms length.

${ }^{127}$ RBSGA - NWB/1358, NatWest, 'NatWest Update' circular, no. 56, 'Developing Technology', January 1986.

${ }^{128}$ RBSGA - unpublished research note compiled by Group Archives.

${ }^{129}$ BGA, 'Barclays Fact Sheet - Cash Machines', undated. Note compiled by Barclays Group Archives. Interestingly, Barclays 'drive in' came some twenty years after similar facilities had been tried and tested in other countries. Some of these remained a part of every day life (i.e. USA) while others were very short lived (i.e. Mexico).

${ }^{130}$ Anonymous, Barclays Fact Sheet: Cash Machine, undated note prepared by Barclays Group Archives.

${ }^{131}$ McAndrews, "The Evolution of Shared Atm Networks," 4.

${ }^{132}$ Barrie, "The Impact of Information Technology on Uk Banking: The Case of Automated Teller Machines", 74

${ }^{133}$ RBSGA - NWB/914/12, NatWest, news release 288/98, 1 December 1988.

134 The UK's Retail Price Index (base January 13 1987), was 160.0 at the end of December 1997 (http://www.statistics.gov.uk/rpi, accessed 07 Jun 2007). The deflated value of NatWest's average withdrawals in 1997 is then $£ 28.20$ or 2 per cent below $£ 28.62$ observed at the end of 1986 .

${ }^{135}$ RBSGA - unpublished research note compiled by Group Archives.

${ }^{136}$ John K. Galbraith, The New Industrial State, ed. Sean Wilentz, 4th (2005) Foreword bJames K Galbraith ed., The James (Princeton and Oxford: Princeton University Press, 1967).

${ }^{137}$ Cortada, The Digital Hand, Vol. 2, 15. 
Figure 1: Voucher to Operate Barclaycash Machines, circa 1967

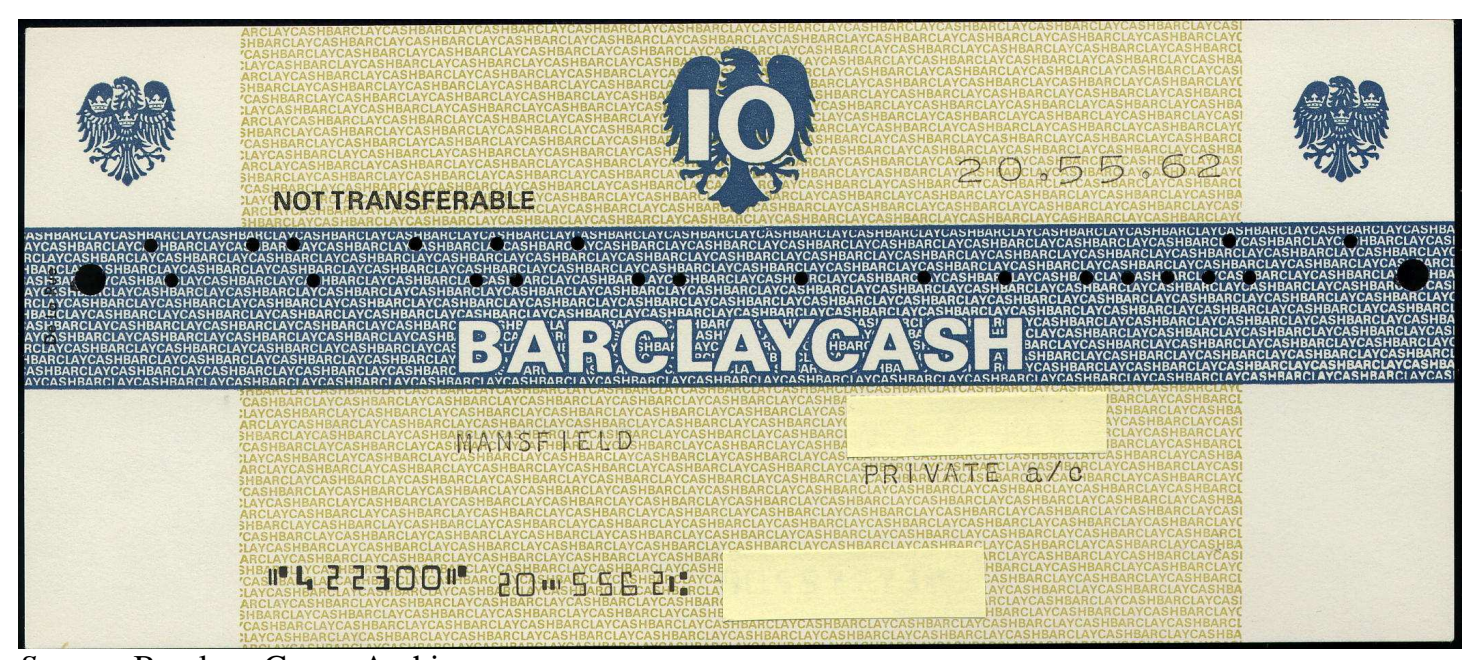

Source: Barclays Group Archive. 
Figure 2: Token to Operate Chubb MD2 Dispensers, circa 1967

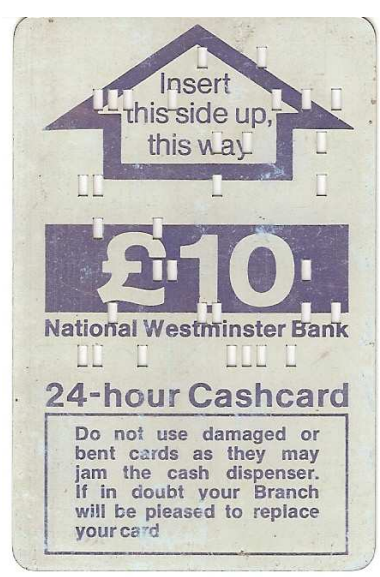

Source: Ian Ormerod NCR UK Retirement Fellowship. 
Table 1

Growth of Installed ATM Units and Value of Daily Transactions between 1967 and 2006

\begin{tabular}{|c|c|c|c|c|c|c|c|c|c|}
\hline & $\begin{array}{c}\text { In } \\
\text { Gourlay } \\
\text { (1999) }\end{array}$ & $\begin{array}{l}\text { talled } A^{\prime} \\
\text { Barrie } \\
(\mathbf{2 0 0 6 )}\end{array}$ & $\begin{array}{l}\text { Is } \\
\text { RBR } \\
(2007)\end{array}$ & Average & Change & $\begin{array}{c}\text { Total Value } \\
\text { of } \\
\text { Transactions } \\
\text { (£m) } \\
\end{array}$ & Change & $\begin{array}{c}\text { Avg Value } \\
\text { of Daily } \\
\text { Transactions }\end{array}$ & Change \\
\hline 1967 & $\mathrm{n} / \mathrm{a}$ & $\mathrm{n} / \mathrm{a}$ & 192 & 192 & $0 \%$ & $\mathrm{n} / \mathrm{a}$ & $\mathrm{n} / \mathrm{a}$ & $\mathrm{n} / \mathrm{a}$ & $\mathrm{n} / \mathrm{a}$ \\
\hline 1968 & $\mathrm{n} / \mathrm{a}$ & $\mathrm{n} / \mathrm{a}$ & 355 & 355 & $85 \%$ & $\mathrm{n} / \mathrm{a}$ & $\mathrm{n} / \mathrm{a}$ & $\mathrm{n} / \mathrm{a}$ & $\mathrm{n} / \mathrm{a}$ \\
\hline 1969 & $\mathrm{n} / \mathrm{a}$ & $\mathrm{n} / \mathrm{a}$ & 595 & 595 & $68 \%$ & $\mathrm{n} / \mathrm{a}$ & $\mathrm{n} / \mathrm{a}$ & $\mathrm{n} / \mathrm{a}$ & $\mathrm{n} / \mathrm{a}$ \\
\hline 1970 & $\mathrm{n} / \mathrm{a}$ & $\mathrm{n} / \mathrm{a}$ & 646 & 646 & $9 \%$ & $\mathrm{n} / \mathrm{a}$ & $\mathrm{n} / \mathrm{a}$ & $\mathrm{n} / \mathrm{a}$ & $\mathrm{n} / \mathrm{a}$ \\
\hline 1971 & $\mathrm{n} / \mathrm{a}$ & $\mathrm{n} / \mathrm{a}$ & 738 & 738 & $14 \%$ & $\mathrm{n} / \mathrm{a}$ & $\mathrm{n} / \mathrm{a}$ & $\mathrm{n} / \mathrm{a}$ & $\mathrm{n} / \mathrm{a}$ \\
\hline 1972 & $\mathrm{n} / \mathrm{a}$ & $\mathrm{n} / \mathrm{a}$ & 925 & 925 & $25 \%$ & $\mathrm{n} / \mathrm{a}$ & $\mathrm{n} / \mathrm{a}$ & $\mathrm{n} / \mathrm{a}$ & $\mathrm{n} / \mathrm{a}$ \\
\hline 1973 & 230 & $\mathrm{n} / \mathrm{a}$ & 1,243 & 737 & $-20 \%$ & $\mathrm{n} / \mathrm{a}$ & $\mathrm{n} / \mathrm{a}$ & $\mathrm{n} / \mathrm{a}$ & $\mathrm{n} / \mathrm{a}$ \\
\hline 1974 & 337 & $\mathrm{n} / \mathrm{a}$ & 1,491 & 914 & $24 \%$ & $\mathrm{n} / \mathrm{a}$ & $\mathrm{n} / \mathrm{a}$ & $\mathrm{n} / \mathrm{a}$ & $\mathrm{n} / \mathrm{a}$ \\
\hline 1975 & 568 & 568 & 1,873 & 1,003 & $10 \%$ & 111 & $0 \%$ & 542.84 & $0 \%$ \\
\hline 1976 & 676 & 676 & 2,055 & 1,136 & $13 \%$ & 177 & $59 \%$ & 727.32 & $34 \%$ \\
\hline 1977 & 875 & 875 & 2,221 & 1,324 & $17 \%$ & 281 & $59 \%$ & 892.06 & $23 \%$ \\
\hline 1978 & 1,000 & 1,005 & 2,221 & 1,409 & $6 \%$ & 460 & $64 \%$ & $1,271.42$ & $43 \%$ \\
\hline 1979 & 1,184 & 1,184 & 2,273 & 1,547 & $10 \%$ & 733 & $59 \%$ & $1,719.69$ & $35 \%$ \\
\hline
\end{tabular}




\begin{tabular}{|c|c|c|c|c|c|c|c|c|c|}
\hline & $\begin{array}{c}\text { In } \\
\text { Gourlay } \\
(1999)\end{array}$ & $\begin{array}{l}\text { talled A' } \\
\text { Barrie } \\
(\mathbf{2 0 0 6 )}\end{array}$ & $\begin{array}{l}\mathbf{s} \\
\text { RBR } \\
(2007)\end{array}$ & Average & Change & $\begin{array}{c}\text { Total Value } \\
\text { of } \\
\text { Transactions } \\
\text { (£m) } \\
\end{array}$ & Change & $\begin{array}{c}\text { Avg Value } \\
\text { of Daily } \\
\text { Transactions }\end{array}$ & Change \\
\hline 1980 & 1,735 & 1,707 & 2,585 & 2,009 & $30 \%$ & 1,316 & $80 \%$ & $2,141.51$ & $25 \%$ \\
\hline 1981 & 2,805 & 2,807 & 3,227 & 2,946 & $47 \%$ & 2,540 & $93 \%$ & $2,513.56$ & $17 \%$ \\
\hline 1982 & 3,928 & 4,061 & 4,149 & 4,046 & $37 \%$ & 4,290 & $69 \%$ & $2,934.42$ & $17 \%$ \\
\hline 1983 & 5,481 & 5,740 & 5,631 & 5,617 & $39 \%$ & 6,597 & $54 \%$ & $3,192.51$ & $9 \%$ \\
\hline 1984 & 6,680 & 6,815 & 6,886 & 6,794 & $21 \%$ & 9,751 & $48 \%$ & $3,974.48$ & $24 \%$ \\
\hline 1985 & 8,664 & 8,845 & 9,168 & 8,892 & $31 \%$ & 12,401 & $27 \%$ & $3,894.54$ & $-2 \%$ \\
\hline 1986 & 10,032 & 10,330 & 10,578 & 10,313 & $16 \%$ & 15,590 & $26 \%$ & $4,192.21$ & $8 \%$ \\
\hline 1987 & 11,749 & 12,392 & 12,389 & 12,177 & $18 \%$ & 18,848 & $21 \%$ & $4,224.95$ & $1 \%$ \\
\hline 1988 & 13,342 & 13,980 & 14,116 & 13,813 & $13 \%$ & 24,320 & $29 \%$ & $4,832.30$ & $14 \%$ \\
\hline 1989 & 15,235 & 15,746 & 16,100 & 15,694 & $14 \%$ & 31,948 & $31 \%$ & $5,636.00$ & $17 \%$ \\
\hline 1990 & 16,730 & 17,344 & 17,353 & 17,142 & $9 \%$ & 38,474 & $20 \%$ & $6,161.91$ & $9 \%$ \\
\hline 1991 & 17,466 & 18,101 & 18,237 & 17,935 & $5 \%$ & 52,080 & $35 \%$ & $7,992.19$ & $30 \%$ \\
\hline 1992 & 18,258 & 18,652 & 18,761 & 18,557 & $3 \%$ & 55,975 & $7 \%$ & $8,336.16$ & $4 \%$ \\
\hline 1993 & $\mathrm{n} / \mathrm{a}$ & 19,140 & 19,377 & 19,259 & $4 \%$ & 60,200 & $8 \%$ & $8,736.79$ & $5 \%$ \\
\hline 1994 & $\mathrm{n} / \mathrm{a}$ & 19,957 & 20,165 & 20,061 & $4 \%$ & 65,170 & $8 \%$ & $9,070.89$ & $4 \%$ \\
\hline
\end{tabular}

